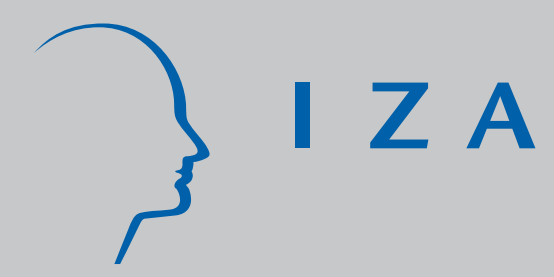

IZA DP No. 2510

The Evolution of Citizenship:

Economic and Institutional Determinants

Graziella Bertocchi

Chiara Strozzi

December 2006 


\title{
The Evolution of Citizenship: Economic and Institutional Determinants
}

\author{
Graziella Bertocchi \\ Università di Modena e Reggio Emilia, \\ CEPR, CHILD and IZA Bonn \\ Chiara Strozzi \\ Università di Modena e Reggio Emilia
}

Discussion Paper No. 2510

December 2006

\author{
IZA \\ P.O. Box 7240 \\ 53072 Bonn \\ Germany \\ Phone: +49-228-3894-0 \\ Fax: +49-228-3894-180 \\ E-mail: iza@iza.org
}

\begin{abstract}
Any opinions expressed here are those of the author(s) and not those of the institute. Research disseminated by IZA may include views on policy, but the institute itself takes no institutional policy positions.
\end{abstract}

The Institute for the Study of Labor (IZA) in Bonn is a local and virtual international research center and a place of communication between science, politics and business. IZA is an independent nonprofit company supported by Deutsche Post World Net. The center is associated with the University of Bonn and offers a stimulating research environment through its research networks, research support, and visitors and doctoral programs. IZA engages in (i) original and internationally competitive research in all fields of labor economics, (ii) development of policy concepts, and (iii) dissemination of research results and concepts to the interested public.

IZA Discussion Papers often represent preliminary work and are circulated to encourage discussion. Citation of such a paper should account for its provisional character. A revised version may be available directly from the author. 


\title{
ABSTRACT \\ The Evolution of Citizenship: Economic and Institutional Determinants ${ }^{*}$
}

\begin{abstract}
We investigate the origin and evolution of the legal institution of citizenship from a political economy perspective. We compile a new data set on citizenship laws across countries of the world which documents how these institutions have evolved in the postwar period. We show that, despite a persistent impact of the original legislation, they have responded endogenously and systematically to a number of economic determinants, such as migration, the size of government, and the demographic structure of the population. Overall, a large stock of migrants decreases the probability of adoption of a mix of jus soli and jus sanguinis provisions, while it pushes jus sanguinis countries toward the adoption of jus soli elements. The welfare burden proves not to be an obstacle for a jus soli legislation, while demographic stagnation encourages the adoption of mixed and jus soli regimes. We also gauge the potential role of legal, political and cultural determinants, and find that a jus sanguinis origin is a factor of resistance to change, that a high degree of democracy promotes the adoption of jus soli elements while the instability of state borders associated with decolonization impedes it, and that cultural factors have no impact.
\end{abstract}

JEL Classification: P16, K40, F22, O15

Keywords: $\quad$ citizenship laws, international migration, legal origins, democracy, borders

Corresponding author:

Graziella Bertocchi

Dipartimento di Economia Politica

Università di Modena e Reggio Emilia

Viale Berengario 51

I-41100 Modena

Italy

E-mail: bertocchi.graziella@unimore.it

\footnotetext{
* We would like to thank J.-P. Azam, G. Barlevy, D. J. DeVoretz, D. Fiaschi, N. Gennaioli, A. M. Mayda, D. Mitra, L. Rocco, K. Tatsiramos, and discussants and participants at the North American Summer Meetings of the Econometric Society, the WDI/CEPR Conference on Transition Economics, the Conference on Economic Growth and Distribution, the CEPR Conference on Understanding Productivity Differences Across Sectors, Firms and Countries, AIEL, ENGIME, ESPE, the CEPR Conference on Institutions, Policies and Economic Growth, the CEPR Conference on The Long Run Growth and Development of the World Economy: Measurement and Theory, the Winter Meeting of the Econometric Society, the 2nd IZA Migration Meeting, the 4th Europaeum Economic Workshop, the CNR Workshop on International Economics and Development, and seminas in Paris, Padua, Toulouse, Milan, Bologna, IZA and Berlin, for helpful comments and suggestions on previous drafts. Financial support from the Italian University Ministry and the European Commission is gratefully acknowledged.
} 


\section{Introduction}

Each country of the world has established a complex system of rules that govern the attribution of citizenship. As a consequence of the increasing pressure of international migration, citizenship laws have moved to center stage on policy agendas., since citizenship laws not only affect the design of immigration policy, but also interact with the workings of labor markets, affect welfare programs, and influence demographic trends.

Citizenship is the legal institution that designates full membership in a state and the associated rights and duties. It provides benefits such as the right to vote, better employment opportunities, the ability to travel without restrictions, legal protection in case of criminal charges, and the possibility to obtain a visa for a relative. There are also costs to citizenship, such as the military draft, renunciation of the original citizenship, and the pecuniary and non pecuniary costs that may be required for naturalization and for recognition at the age of majority. Examples are language and culture tests, waiting periods, and a commitment to avoid activities leading to disqualification).

There are several ways to acquire citizenship: at birth, by naturalization, by marriage. Citizenship at birth, which regulates citizenship acquisition by second-generation immigrants, is rooted in the well-defined bodies of common and civil law (Weil, 2001). The former traditionally applies the jus soli principle, according to which citizenship is attributed by birthplace: this implies that the child of an immigrant is a citizen, as long as he is born in the country of immigration. The latter applies the jus sanguinis principle, which attributes citizenship by descent, so that a child inherits citizenship from his parents, independently of where he is born. Despite being rooted in these principles, during the 20th century - and especially after World War II - citizenship laws have gone through a process of continuous adaptation, in conjunction with the decolonization phase, the collapse of the socialist system, and the mounting pressure of international migration.

In this paper we investigate empirically the determinants and evolution of citizenship laws in the postwar period from a political economy perspective. Our first goal is to assemble a new data set which codifies citizenship laws across the countries of the world, with a specific focus on the provisions that regulate the access to citizenship at birth. The data set is then 
used to study the dynamic adaptation of these laws, by relating the observed patterns to a number of potential determinants, including economic factors as well as other political and cultural factors which have been found relevant in related research on institutions.

Modern sociopolitical theories have advanced several hypotheses concerning the determinants of citizenship laws dynamics, on the basis of case studies and non-quantitative cross country comparisons. The legal tradition established in a given country is generally believed to exert a persistent impact on current legislation. The relevance of economic forces is also recognized. In particular, pressure from a large stock of migrants is perceived as a factor that shapes a country's attitude toward citizenship policy. On the one hand, it could push toward a legislation that allows automatic citizenship granting for all newborn. On the other, immigration could also drive toward restrictions of the same principle in countries where it was originally applied. According to some sociopolitical theories, the combination of these forces tends to induce convergence toward a mix of jus soli and sanguinis provisions for countries coming from different legal traditions (Weil, 2001). Moreover, since citizenship rights also determine the ability to enjoy welfare benefits, the shaping of nationality laws has been linked with the nature of the welfare state, with a large government representing a potential obstacle to the retention of jus soli (Joppke, 1998). This argument, however, has to be weighted against the potential gain coming from the acquisition of relatively young new citizens for countries with expensive pension systems and in the midst of a demographic crisis. Political factors have also been found relevant. The presence of a consolidated democracy is expected to lead to the adoption of jus soli, viewed as a more equal treatment of aliens. Stabilization of state borders should reduce the pressure to preserve a national identity through jus sanguinis. Finally, an additional factor that has been the subject of debate is the influence of national character and culture. The theory advanced by Brubaker (1992) focuses on France and Germany as two antagonistic kinds of nationhood, the former more assimilationist, the latter more ethnocentric, which also differ in their definitions of citizenship.

This paper tests the above hypotheses in a political economy perspective and finds that in the postwar period citizenship laws have responded endogenously and systematically, through a slow but steady process of adaptation, to the following economic and institutional factors. First, the presence of a large stock of migrants has not shaped national legislations in 
the direction of convergence toward a mixed regime including both jus soli and jus sanguinis elements. Second, there is evidence of a tendency toward adding jus soli provisions for those jus sanguinis countries which have experienced large immigration. Other economic factors also matter. While the welfare burden proves not to be an obstacle for a jus soli legislation, demographic stagnation encourages the adoption of mixed and jus soli regimes. Turning to institutional factors, we find that the persistence of legal tradition is confirmed by our data, with a particularly strong tendency for jus sanguinis to be preserved. We also find that a high degree of democracy is significantly associated with a jus soli legislation, while border instability, in particular following the decolonization phase, decreases its likelihood. Cultural characteristics are not found to play a significant role.

The rest of the paper is organized as follows. Section 2 introduces the related literature. Section 3 reviews the historical and legal background for the issues we address. Section 4 describes our data set on citizenship laws around the world. Section 5 investigates the determinants of current citizenship laws and presents our main results, together with a set of robustness checks. Section 6 develops an alternative empirical strategy that highlights the determinants of change in citizenship laws. Section 7 concludes and indicates directions for future research. The Data Appendix collects information about the data employed.

\section{Related literature}

Our work is related with several branches of the economic literature. First of all, this paper adds to research on international migration and migration policy. Timmer and Williamson (1998), Hatton and Williamson (2006) and Bertocchi and Strozzi (2006) empirically analyze immigration policies enacted at the end of the 19th century during the mass migration era, while O'Rourke and Sinnott (2005) and Mayda (2005) estimate voters' attitudes toward immigration in the postwar period. The political economy of migration has been modeled, among others, by Benhabib (1996), Razin et al. (2002), Gradstein and Schiff (2006), and DeVoretz (2006). More specifically, the role of citizenship policy has been discussed by DeVoretz and Pivnenko (2006), who investigate the economic costs and benefits derived from citizenship, and by Pritchett (2006), who evaluates citizenship policy within a broader 
discussion on labor mobility and immigration policies.

More broadly, our work contributes to the research program which has focused on the historical determinants of institutions. Engerman and Sokoloff (2002) highlight the relevance of wealth inequality and political factors in accounting for how fundamental economic institutions developed over time. Acemoglu et al. (2001) contribute to the understanding of how institutions evolve by using historical variables as instruments for contemporary measures of the quality of institutions.

This paper also relates to the comparative legal approach initiated by La Porta et al. (1998). The basic premise of this research line is the recognition that laws in different countries are adopted or transplanted from a few legal traditions and that the resulting legislative bodies reflect both the influence of the legal origin and the subsequent revision specific to individual countries. We add to this stream by focusing on the determinants of the dynamic adaptation of nationality rules.

Finally, recent work by Alesina and Spolaore (1997) and Bolton and Roland (1997) on the optimal determination of the size of nations, and thus state borders, is also relevant to our approach, both because country size in this literature is the same as population size and is potentially influenced by migration and by the legal status of immigrants, and also because borders play an important role on the determination of citizenship rules.

\section{Citizenship laws in historical perspective}

Citizenship policy can be viewed as part of broader migration policy. However, contrary to other migration policy measures such as quotas and visa requirements, that are typically adjusted to the business cycle and to the current government orientation, citizenship laws reforms tend to be the outcome of long-term processes of adaptation often involving constitutional amendments.

In 18th century Europe jus soli was the dominant criterion, following feudal traditions which linked human beings to the lord who held the land where they were born. The French Revolution broke with this heritage and with the 1804 civil code reintroduced the ancient Roman custom of jus sanguinis. Continental modern citizenship law was subsequently built on 
these premises. During the 19th century the jus sanguinis principle was adopted throughout Europe and then transplanted to its colonies. By imitation, Japan also adopted jus sanguinis in this phase. On the other hand, the British preserved their jus soli tradition and spread it through their own colonies, starting with the United States where it was later encoded in the Constitution. By the end of the 19th century, the process of nation-state formation and the associated codification effort were completed in Continental Europe. At the same time, the revolutionary phase was over in those countries that had been the subject of the earlier colonization era, and 19th century colonization had extended the process of transplantation of legal tradition to the rest of the world. Therefore, by that stage, most countries of the world had established specific provisions regarding citizenship acquisition within a relatively well-developed legal system, with jus soli being the norm in common law countries, and jus sanguinis regulating citizenship law in most civil law countries, despite important exceptions. For instance, civil law Latin America had embraced jus soli early on, while civil law France, with its colonies, had by then already moved toward a mixed regime. However, the next century witnessed a continuous process of transformation of citizenship laws across the world. Below are some specific cases, drawing mostly from Joppke (1998), Aleinikoff and Klusmeyer (2000, 2001) and Brubaker (1992).

The United States Jus soli was encoded in the US Constitution through the 1868 Fourteenth Amendment, with the specific purpose to protect the birthrights of black slaves. Consistently with its history as a country of immigrants, and with a general positive attitude toward economic liberalism, the US approach is still remarkably consistent with its original attitude in all its aspects, ranging from immigration policy to naturalization requirements. Debate about possible restrictions did arise recently, but never led to actual change. ${ }^{1}$ In particular, jus soli came under attack in the 1980s regarding its applicability to the children of illegal immigrants. A relatively young and thin welfare state contributes to the fiscal sustainability of jus soli in this country. ${ }^{2}$

\footnotetext{
${ }^{1}$ In his analysis of Mexican immigration, Huntington (2004) has criticized current nationality regulations on the grounds that they represent a "devaluation of citizenship". Pritchett (2006) discusses the possible advantages of guest-worker programs which do not contemplate citizenship, from the perspective of poor countries.

${ }^{2}$ The relative thickness of the concept itself of citizenship, if compared to residency, is a related, potentially
} 
Australia Current citizenship law in Australia differs considerably from that of the United States, despite the common origin as countries of immigration. Jus soli had also been introduced in Australia by the colonists. In the postwar period, the country went through numerous legislative and administrative reforms. Jus soli survived until 1986, while afterwards a person born in Australia must have at least one parent who is either an Australian citizen or a permanent resident in order to acquire citizenship.

Latin America In the face of a civil law tradition which had been transplanted by the European powers, this area has followed a rather peculiar pattern. At independence, most of the incipient states chose jus soli as a way to break with the colonial political order and to prevent the metropoles from making legitimate claims on citizens born in the new countries. Jus soli was encoded in the Constitution of Brazil in 1824, of Venezuela in 1830, of Argentina in 1853. Therefore, most of Latin America was already a jus soli country before the 19th century immigration waves began. Jus soli is still the prevalent rule in the area, even if it is no longer attracting immigrants. Mexico represents a special case where jus soli was also adopted in the 1814 insurgent Constitution, but was then abandoned in 1836, only to come back to stay with a Constitutional Amendment in 1937.

The United Kingdom British nationality law has been deeply affected by the imperial experience. Because of its colonial history, the concept of nationality in the UK was, up to World War II, particularly extensive, since all subjects of the British Empire had equal access to British citizenship simply by establishing residence in the UK. The 1948 Nationality Act created the status of Citizen of the United Kingdom and Colonies for people with a close connection to the UK and its colonies. Following a postwar wave of colonial immigration, this open-door policy was progressively restricted, even though special status is still attributed to citizens of the British Commonwealth. Redefinitions of national citizenship have been effectively employed, since the 1980s, as a form of selective immigration policy. The 1984 British Nationality Act restricts jus soli by establishing that a child born in the UK qualifies for British citizenship only if at least one parents is a British citizen or resident.

relevant consideration: in the US, for instance, citizenship is relatively thin, in the sense that it confers few additional benefits if compared with residency. 
France The emergence of the nation-state in Continental Europe was the main factor that shaped citizenship law in this area. The revolutionary experience was particularly important for France, where jus sanguinis was first introduced with the 1804 Civil Code and maintained for the entire course of the 19th century, even though military consideration introduced early on elements of jus soli. In order to secure immigrants' children born in France to the draft, in 1889 double jus soli became automatic, making the experience of this country a unique one. After World War II, large-scale immigration, especially from North Africa, raised concern regarding assimilation. Citizenship issues and the rights of immigrants became the object of heated debate in French politics. In 1993 Chirac introduced a restrictive revision to the legislation, that required a formal citizenship request from second-generation immigrants. With the Left regaining political power in 1997, however, these restrictions were considerably revised, with the automatic assignment of citizenship at age 18 to those immigrants' children born in France who had neither requested, nor declined it. The case of France is frequently compared with Germany. Brubaker (2002) has influentially argued that the different path followed by these countries has been shaped by their cultural difference, with France sticking to its tradition of assimilationist nation, and Germany to its ethnic identity.

Germany The single most relevant event in the history of German citizenship law is certainly the fall of the Berlin wall, which paved the way for the achievement of stable national borders. Prior to that, the massive guest-worker immigration of the postwar period, mostly from Turkey but also from Southern Europe, had started to put under strong pressure, but to no avail, the original Wilhelminian citizenship law of 1913, which had established strong sanguinis ties with German overseas emigrants. With the foundation of the GDR and the consolidation of the Eastern Block, Germany found itself in the paradoxical situation of having to live with a large population of disenfranchised foreigners born on its soil at home, and at the same time with millions of ethnic Germans living behind the Iron Curtain. Achieving border stability was a decisive factor in pushing Germany toward the long-delayed adoption of jus soli elements. A first step in this direction was the new Foreigner Law in 1990, which turned naturalization from the discretionary exception into the rule. A major overhaul of the legislation, following an intense political struggle, was finally approved in 1999. Jus soli is now the norm in Germany (under the mild requirement that one parent has lived in the 
country for eight years). In the evaluation of the German experience, other factors that may have delayed the introduction of jus soli are, as mentioned in the introduction, the strong ethnic character of German national identity, and the thick nature of the German welfare state. The latter aspect may have played a role in shaping the evolution of citizenship policies in several other European countries and especially the Scandinavian ones, where jus sanguinis was functional to the large past emigration flows, but had recently to adapt to the quickly changing conditions, especially for high-immigration Sweden. As documented by Weil (2001), restricted forms of double jus soli are de facto applied, by now, in the vast majority of European countries, which recently adapted their legislation to the globalization of international migration and its increasing impact on Europe. In particular, in the entire EU, with the exceptions of Austria, Greece and Luxembourg, access to citizenship by second and third generation is facilitated.

Decolonization Postwar decolonization had a major impact on citizenship rules applied around the world, and not only through the indirect impact on the metropolitan countries we previously examined. The vast majority of the African colonies that were subject to civil law countries practicing jus sanguinis stuck to this principle after independence. On the other hand, many former UK and Portuguese colonies rejected the jus soli tradition and switched to an often strongly ethnically-tinged version of jus sanguinis. For instance, Sierra Leone's 1961 Constitution established that citizenship is transmitted only by descent and only to children whose father and a grandfather were Sierra Leoneans of African-Negro descent. In situations where instability was pushed to an extreme degree by the young age and the arbitrary borders of these countries, and was compounded with deep ethnic division, jus sanguinis tended to prevail as a way to control more easily the formation of national entities. At the same time, however, the associated exclusive notion of ethnic and tribal identity caused enormous problems in countries where colonial rule had left shaky democratic institutions. To these days, ethnic conflict lies at the roots of a chronic manipulation of citizenship rules in favor of one ethnic group over others. The 1964 Congolese Constitution, in an effort to exclude Rwandan immigrants, recognized citizenship only for persons whose parents were members of one of the tribes established within the territory by 1908. In 1981 Mobutu signed a new law on nationality requiring an ancestral connection to the population residing in the 
territory as far back as 1885. Marginalization and de facto statelessness of significant strata of the population is the unavoidable outcome of these policies.

The disintegration of the USSR Another major wave of citizenship law codification followed the disintegration of the USSR. The area had been sealed toward international migration but, as for all empires, there had been considerable migration within. The Soviet Union had occupied Estonia, Latvia and Lithuania in 1940. During the following decades millions of Russians were encouraged to settle in Latvia and Estonia (less so in Lithuania) in order to Russify them. To these days, large Russian-speaking, stateless, sizeable minorities are still present. After independence, the new citizenship laws of these three states reflected this heritage with an emphasis on jus sanguinis as the basis for acquiring citizenship. The hostile attitude toward ethnic Russians was especially strong in Latvia, while Lithuania, which was less affected by Soviet immigration policy, showed a more open approach. The issue for these states was how to balance a need to reconstitute their national identity around an ethnic model, and a commitment to democratic values with respect to the rights of minorities. Estonian and Latvian laws were sharply criticized by international organizations on the grounds of human rights. In the anticipation of EU integration, these recommendations were indeed fulfilled in the more recent legislation of the Baltics, while most other countries of the area still persist with discriminatory policies. By contrast, for the case of the Russian Federation, the salient fact in shaping current citizenship policy is the perception that many of its citizens are outside its borders, spread around the former regions of the USSR. Again, this perception as a country of emigrants pushes toward the persistence of jus sanguinis as the main principle, even though small concessions to jus soli have been made.

\section{The data: Citizenship laws of the world}

We compile a data set of citizenship laws across the countries of the world for the postwar period. The principal source for the information we codify is a directory published by the Investigations Service of the United States Office of Personnel Management in 2001, which provides synopses of the citizenship laws currently practiced in 190 countries. The sources for this directory were Embassies, the Library of Congress, and the Department of State. 
We supplement this information with additional one from the CIA World Factbook (2002), the United Nations High Commission for Refugees (2003), and the survey in Weil (2001).

The principal focus of our codification is citizenship acquisition at birth, but we also collect information about naturalization requirements.

\subsection{Citizenship at birth}

We attribute to each country an appropriate code for citizenship laws in 2001, 1975 and at the beginning of the postwar period. We take 1948 as the starting point, even though there were nearly no reforms in citizenship laws during the first half of the century, so that most of the legislation in place in 1948 had actually been developed much earlier. ${ }^{3}$ As in the analysis of legal origins in La Porta et al. (1998), we treat the specific legal provisions regulating access to citizenship in 1948 as predetermined, at least relative to the subsequent developments that are the focus of the present investigation. Indeed, while the 19th century witnessed a first wave of adaptation of citizenship legislation from the civil vs. common law tradition, the subsequent half century did not see further evolution, despite the occurrence of major historical events such as World War I. By coding citizenship laws in the intermediate year 1975, we divide the postwar period into two subperiods of equal length.

In our classification we focus on the presence of jus soli elements in a country's legislation. This approach is justified by our primary interest in the potential impact of citizenship laws on immigrants, rather than emigrants. For 1948, 1975 and 2001, we divide countries into three groups: countries subject to jus sanguinis without any jus soli element (Group 1), countries that apply a mixed regime (Group 2), and countries subject to full jus soli (Group 3). A mixed regime includes elements of both jus soli and jus sanguinis. ${ }^{4}$ Our data set includes those 162 countries for which we were able to collect information on both original and current citizenship laws, and for which migration data were available for the postwar

\footnotetext{
${ }^{3}$ By treating 1948 as the initial year, we include the postwar decolonization phase with the exemption of the Middle East, which gained independence from the British and French administration in the 1943-1948 period.

${ }^{4}$ For details on our classification criteria see the Data Appendix, part A.
} 
period..$^{5}$

The differential patterns of evolution that citizenship laws generate in 1948, 1975 and 2001 are summarized by the transition matrices in Table 1, which reveals considerable variations both across countries and over time. The table shows that in 1948 jus soli was the rule in about $47 \%$ (i.e., 76 out of 162) of the countries, while jus sanguinis dominated in $41 \%$ (i.e., 67 out of 162), and the mixed regime was adopted in the remaining 12\% (19 countries). Among the countries that were under jus soli in 1948, we find the United States, Canada, all the Oceanian countries, most of Latin America, within Africa and Asia the British and Portuguese colonies, within Europe the UK, Ireland and Portugal. On the other hand, in 1948 jus sanguinis predominated in most of Europe, including its Eastern part. As explained in Section 3, France was unique in its early choice of a mixed regime. Since we treat colonial territories as subject to the metropolitan countries' regime until independence, the group applying the mixed regime in 1948 includes France and its colonies.

By 1975, 31\% (i.e., 50 out of 162) of the countries had jus soli, $62 \%$ (101) jus sanguinis, and $7 \%$ (11) a mixed regime. The main event justifying this evolution is decolonization, with many former colonies switching to jus sanguinis, from jus soli when the UK and Portugal were the metropolitan country, and from the mixed regime in the case of France (see Section 3). As of 2001, $24 \%$ (i.e., 39 out of 162) of the countries apply jus soli, $54 \%$ (88) jus sanguinis, and $22 \%$ (35) a mixed regime. It has mostly been the adaptation of the legislation of many European countries, relaxing pure jus sanguinis in favor of a mixed regime, that explains the pattern observed for the second subperiod.

Among the countries that still adhere to the jus soli principle in 2001 are the United States, Canada, New Zealand, and Ireland (which - however - recently introduced restrictions to jus soli with a June 2004 referendum). The United Kingdom and Australia, on the contrary, no longer adhere to it and now adopt a mixed regime. Overall, jus sanguinis is currently the most common regime, with $69 \%$ of the countries in Africa, $83 \%$ in Asia, and $41 \%$ (down from 88\%) in Europe. The growing group where a mix of provisions is applied is particularly well-represented in Europe, with $56 \%$ of the European countries including the formerly jus soli United Kingdom. On the other hand, jus soli predominates in the Americas,

\footnotetext{
${ }^{5}$ For details on migration data see the Data Appendix, part C.
} 
with $89 \%$ of the countries in Latin America, and the entire North America (i.e., the US and Canada).

Table 1 reveals three different patterns of transitional dynamics: stability, switch, and convergence. Stable countries lie along the diagonal. Looking at the 1948 to 2001 transition, we see that a large fraction (28\%, i.e., 46 out of 162) have started and ended as jus sanguinis. In other words, it is $69 \%$ (i.e., 46 out of 67 ) of the originally jus sanguinis countries that have remained so. By contrast, 22\% (36 out of 162) are steadily jus soli countries: this means that only $47 \%$ (36 out of 76 ) of the originally jus soli countries have not changed their policies. Off diagonal, there is a sizeable proportion of countries $(19 \%$, or 31 out of 162) that have switched from jus soli to sanguinis, by completely eliminating birthplace as a criterion: most of them - as mentioned - are former African colonies of the UK and Portugal, which made this radical choice at independence. Looking at the two subperiods, we see most of these switches occur between 1948 and 1975. Finally, there is evidence of a process of convergence to a soli/sanguinis mix, which affects $18 \%$ of the countries (29 out of 162, of which 20 converge from jus sanguinis by adding jus soli elements, while 9 converge from jus soli by restricting it) and intensifies between 1975 and 2001.

In Table 2 we present further information on citizenship laws evolution by reporting changes in citizenship laws, organized by original laws. Over the 1948-2001 period, 74 countries $(46 \%)$ have gone through a change in the laws, with 45 changes occurring in the first subperiod, and 33 in the second. ${ }^{6}$ In particular, in the first subperiod, the majority of the countries that went through a change $(29$, or $64 \%)$ were originally jus soli. As mentioned, this pattern is determined largely by the behavior of former colonies. In the second subperiod, the majority of the countries that went through a change $(20$, or $61 \%$ ) were originally jus sanguinis, most of which adopting a more open legislation.

Summary statistics for our citizenship laws data set are reported in Table 3. The correlation between 1948 and 2001 citizenship laws is 0.42, which points to some persistence, as confirmed by the even higher correlation between 1948 and 1975 (0.60) and 1975 and 2001 laws (0.81).

\footnotetext{
${ }^{6} \mathrm{~A}$ few countries went through more than one change.
} 


\subsection{Citizenship by naturalization and the citizenship policy index}

Naturalization policies are also relevant to the issues at hand. Indeed, to facilitate naturalization for immigrant parents may represent a substitute mechanism to attribute citizenship to children born in jus sanguinis countries. Besides, the general attitude revealed by a country's regulation of citizenship at birth may be reflected in its naturalization laws, with jus soli countries traditionally making naturalization much easier, at least for resident aliens. Within jus sanguinis countries, naturalization requirements again tend to be correlated with the revisions introduced for citizenship at birth. Basic rules for naturalization may include a period of residence, renunciation of other citizenship, familiarity with the language and customs of the country, and the availability of adequate means of support. ${ }^{7}$

We code naturalization only for 2001, on the basis of the available information on 142 of our 162 countries. We classify countries on the basis of the number of years of residence required for naturalization, by constructing four classes (more than 14 years, 6 to 14 years, 5 years, 4 years or fewer). In our data set 62 countries (i.e., 44\%) require five years of residence, which can be considered a relatively open attitude, while $46 \%$ require more time and only $10 \%$ are more open.

We then combine the information we collected on citizenship at birth and naturalization within a single measure, even though data on naturalization are only available for the year 2001 and for a subset of countries. We construct an index of citizenship policy defined on the $0-1$ interval. To construct the index, we treat citizenship laws in 2001 as an ordinal variable, by associating jus soli elements with lower number of years of residence required for naturalization. The corrected Cronbach's alpha of the indicator is only 0.54, which can be explained by the fact that the correlation between citizenship laws and naturalization is 0.37. Alternative ways to define naturalization classes yielded similar conclusions. ${ }^{8}$ Table 3 reports summary statistics for naturalization and the citizenship policy index.

\footnotetext{
${ }^{7}$ We do not consider naturalization by marriage, since it is heavily dependent on family law.

${ }^{8}$ Dual citizenship provisions constitute another potentially relevant aspect of citizenship policy, but we do not use this variable due to limited information.
} 


\section{The determinants of citizenship laws}

\subsection{Empirical specification}

To investigate the determinants of citizenship laws evolution in the postwar period, we estimate regression models with current citizenship laws as dependent variable. Our dependent variable is categorical and can take three values: 1 if the country has a jus sanguinis regime, 2 if the country has a mixed regime, and 3 if the country has a jus soli regime.

We use a multinomial logit specification to achieve maximum generality. In fact, this choice does not impose any ex ante ordering among the three regimes, e.g., an ordering by increasing inclusiveness toward immigrants, with jus soli being associated with maximal, and jus sanguinis with minimal inclusiveness. Moreover, in principle those regressors that affect the probability of being a jus soli country may not always have the opposite effect on the probability of being a jus sanguinis country, or else may not have any effect at all (and vice versa). Further discussion on this point is postponed to the sub-section on robustness.

The sample investigation is performed using a panel sample which includes information on two cross sections of 162 countries: the first cross section refers to the 1950-1975 subperiod, the second cross section to the 1976-2000 subperiod. In the full specification we present, the multinomial logit model we run has the following form:

$$
C_{i t}=a S_{i t}+b M_{i t}+c S_{i t} M_{i t}+d P_{t}+\mathbf{Z}_{i t}^{\prime} \mathbf{e}+\epsilon_{i t},
$$

with $i=1, \ldots, 162$ and $t=1,2$ (where $t=1$ refers to the $1950-1975$ period and $t=2$ refers to the $1976-2000$ period). ${ }^{9}$

In specification (1), $C_{i t}$ represents citizenship laws in country $i$ at the end of period $t, S_{i t}$ is a dummy for the presence of jus sanguinis in country $i$ at the beginning of each subperiod, $M_{i t}$ is migration stock in country $i$ at the beginning of period $t, S_{i t} M_{i t}$ is the interaction between the previous two variables, $P_{t}$ is a period dummy, $\mathbf{Z}_{i t}$ is a vector of additional explanatory variables, and $\epsilon_{i t}$ is the error term. ${ }^{10}$

\footnotetext{
${ }^{9}$ We also run multinomial logit models for two types of more parsimonious specifications, for comparison purposes.

${ }^{10}$ In particular, $C_{i 1}$ and $C_{i 2}$ are citizenship laws in country $i$ in 1975 and 2001, respectively; $S_{i 1}=1$ if country $i$ has jus sanguinis in 1948 and $S_{i 2}=1$ if country $i$ has jus sanguinis in in 1975; $M_{i 1}$ is migration
} 
The set of explanatory variables $\mathbf{Z}_{i t}$ can be divided into two groups. The first group includes dummies capturing the country's geopolitical position. Within this group we consider a set of dummies capturing a country's history of border changes (decolonization, Berlin wall, other border changes $)^{11}$ and dummies for Latin American, Southern European and small countries. The second group of explanatory variables includes a measure of democracy, proxies for cultural characteristics such as religious affiliation and ethnolinguistic fractionalization, the size of government, and the share of young in the population.

The Data Appendix collects information on the definitions and sources of all variables we employed. Table 4 presents their summary statistics.

We can now suggest a number of specific hypotheses regarding the potential role of the above mentioned factors, starting with the variables we consider focal to our analysis, i.e., legal tradition and immigration. Throughout the following, we will organize our comments in terms of the effects of each of our regressors on the probability of adopting either a mixed or a jus soli regime instead of jus sanguinis. This follows the specification of our multinomial logit estimates, where we take jus sanguinis as the reference category.

Legal tradition is identified by a dummy for countries that apply jus sanguinis at the beginning of each subperiod $\left(S_{i t}\right)$. We select this dummy because jus sanguinis is the most persistent of the three regimes, thus suggesting a particularly significant role of this initial legislation. A negative value of the dummy's coefficient for a mixed and jus soli regime would imply that jus sanguinis countries are less likely to end up in the mixed and jus soli groups, thus confirming persistence of the original laws.

Migration $\left(M_{i t}\right)$ is measured by the stock of migrants in percent of the population at the beginning of each subperiod. For the first subperiod, the available data refer to the stock in 1960, while for the second they refer to the stock in 1980. By entering the migrant stock near the beginning of each period, we avoid any potential endogeneity problem of migration with respect to citizenship laws, since it is unlikely that stocks evaluated at the beginning of the period can be affected by subsequent changes in citizenship laws. ${ }^{12}$ A positive coefficient for stock in country $i$ in 1960 and $M_{i 2}$ is migration stock in country $i$ in 1980; $P_{1}=0$ and $P_{2}=1$.

${ }^{11}$ The Data Appendix, part B describes how the three border change dummies are constructed.

${ }^{12}$ Even taking into account the anticipation of future changes of citizenship laws in making migration decisions, the endogeneity of our migration measure is ruled out by the fact that such changes had been 
the mixed regime would indicated that high migration pushes toward it rather than toward jus sanguinis, and similarly for the jus soli regime.

The interaction between the jus sanguinis dummy and migration should reveal additional information: if positive, its coefficients would indicate that those jus sanguinis countries facing high migration tend to add jus soli elements. In particular, a positive coefficient for the mixed regime would suggest convergence toward the intermediate group. On the other hand, the coefficients of the interaction could also turn out to be negative since, in the presence of a large stock of migrants, the natives' reaction could be a conservative one.

Turning to our geopolitical dummies, if border stability really counts as a prerequisite for the introduction of automatic birthrights for the immigrants, as suggested by some of the political theories introduced in Section 1, we should expect negative signs for the coefficients for our border change dummies. We introduce the Latin America dummy to capture the peculiarity of this continent's experience. As explained in Section 3, most of Latin America adopted jus soli long before our sample period, so its current position is not determined by postwar developments and in particular by its postwar migration experience. If indeed the behavior of Latin America differs significantly from the rest of the sample in being associated with a higher probability of adopting jus soli, it should exhibit a positive coefficient for this kind of legislation. For Southern Europe, we should expect a positive coefficient for the mixed regime since these countries have been experiencing quickly increasing migration during the second subperiod, with most of the revision to the legislation toward mixed regimes occurring in the past 15 years or so. Finally, since migration data reveal that countries with a small population tend to have large and erratic figures, with a disproportionately small impact on their legislation, we should expect negative signs for this dummy's coefficients.

The establishment of a consolidated democracy - measured by the political rights variable - should exert a positive effect on the probability of a jus soli legislation even though even in a democratic country hostility toward the assimilation of outsiders may persist for a protracted period of time. The possible impact of cultural factors is proxied here by two different regressors, in an effort to capture several dimensions of cultural differences. In parextremely rare during the first half of the 20th century. The potential endogeneity of migration is further addressed in Section 5.3.1, where alternative measures of migration are introduced. 
ticular, we include the share of Catholics in total population and an index of ethnolinguistic fractionalization.

The size of government is meant to proxy for the nature of the welfare state: if a thicker, more expensive and more redistributive structure would represent an obstacle to automatic citizenship granting to the children of relatively poor immigrants, we would found negative coefficients. On the other hand, if young immigrants could offer a solution to domestic demographic imbalances, we would find that countries with a higher share of young in total population would be less prone to adopt jus soli elements, thus displaying negative coefficients.

Pairwise correlations among our dependent and independent variables are presented in Table 5. Current citizenship laws, the dependent variable, is highly correlated with the initial citizenship laws as identified by the jus sanguinis dummy (-0.64), while its correlation with the civil law dummy is much lower (-0.15). Citizenship laws are also significantly correlated with migration, the small country dummy, political rights, the Catholic share, and ethnolinguistic fractionalization. Pairwise correlations between all our independent variables are not reported for brevity and can be summarized as follows. The dummy reflecting jus sanguinis as the initial law is negatively correlated with decolonization (-0.31) and Latin America (-0.43). The Latin America dummy is positively associated with the Catholic share (0.52). Political rights tend to be low in countries with high ethnolinguistic fractionalization $(-0.36)$. The share of young in population is positively associated with migration stocks (0.35). Overall, these stylized facts are in line with previous research and economic intuition. It is also clear that several of our independent variables are closely interrelated and that it may be difficult to disentangle their specific effect on the evolution of citizenship laws.

\subsection{Results}

The results of our multinomial logits are presented in Table 6. The table reports three different specifications. Multinomial logit (a) is the core specification, which includes only the core variables, i.e., migration and jus sanguinis as initial citizenship law, plus the period dummy. Multinomial logit (b) is an expanded specification, which adds to (a) the dummies we discussed above. Finally, multinomial logit (c) is our full specification, which adds to 
(b) the other potentially relevant economic and institutional regressors. Jus sanguinis is the reference category for all the results shown. Hence, the results reported in the table indicate the impact of the explanatory variable on the probability of choosing either the mixed or the jus soli regimes, relative to jus sanguinis.

Starting with the core specification, we find that the core variables are all significant. In particular, migration and jus sanguinis display negative coefficients for both the mixed regime and jus soli, while both coefficients are positive for the period dummy. This means that high migration and a jus sanguinis origin decrease the probability of applying a mixed or a jus soli legislation rather than jus sanguinis, and that in the second subperiod the probability of applying a mixed or jus soli legislation increases.

In the specification which includes the dummies, the jus sanguinis origin still exerts a negative impact on the probability of applying a mixed or jus soli regime, while migration only remains significantly negative for the probability of applying a mixed regime. The period dummy is significantly positive only for the probability of a mixed regime. As expected, the decolonization dummy displays two negative coefficients, i.e., having gone through a decolonization border change negatively affects the probability of applying either a mixed or jus soli regime. South Europe has a positive coefficient for the mixed regime, confirming that Southern European countries have a higher probability of becoming mixed. Latin America has a positive coefficient for jus soli, since these countries have a higher probability of applying this regime. The small country dummy is not significant in this specification.

Finally, in the full specification, the impact of migration, a jus sanguinis origin and the period dummy are confirmed. ${ }^{13}$ The interaction term between migration and jus sanguinis origin is significant and positive for both the mixed regime and jus soli, uncovering a tendency for countries with a jus sanguinis origin which are exposed to high migration to add jus soli elements (as clarified by the marginal coefficients in Table 7). In this extended version the coefficient for decolonization loses significance. However, inspection of the marginal effects for decolonization (see again Table 7) confirms that even in the full specification the regressor retains a significantly negative impact on the probability of jus soli. ${ }^{14}$ The role

\footnotetext{
${ }^{13}$ For both multinomial logit (a) and (b) we obtain the same results using a balanced sample composed by the 224 countries which constitute the reference sample for the estimation of our full specification.

${ }^{14}$ Moreover, with the mixed regime as the reference category, decolonization displays a significantly nega-
} 
of the Latin America and Southern Europe dummies is confirmed, while the small country dummy now reveals a negative impact on the probability of applying a mixed regime. The size of government has a positive and significant coefficient for the probability of applying a jus soli regime, while the share of young in the population exerts a negative impact, in support of the hypothesis that countries with a relatively old population are more likely to choose mixed and jus soli regimes. The variables meant to capture cultural characteristics, i.e., the share of Catholics and ethnolinguistic fractionalization, are both insignificant, while a high degree of democracy positively affects the probability of applying either a mixed or jus soli regime. ${ }^{15}$

We also consider additional covariates that have often been found significant in related research on the determinants of institutions. Quantitative and qualitative development indicators such as income per capita and inequality could reveal if a richer, more equal country is more prone to adopting jus soli elements. However, both per capita GDP and the Gini index of inequality tend to be associated with migration, and also with democracy and fractionalization, so they are unlikely to add independent explanatory power to a regression. In fact they fail to add any further significance to the previous results. Moreover,.a dummy for oil countries could account for the fact that most of them have been experiencing huge immigration which has had no impact on their still very restrictive legislation (often based on Islamic family law). A dummy for socialist countries could instead work as an alternative to our Berlin wall border change dummy. ${ }^{16}$ However, we cannot include in the regressions the socialist and oil dummies, as well as the Berlin wall and the other border changes dummies, due to the fact that all countries identified by them do not exhibit enough variability with respect to the dependent variable. ${ }^{17}$

Table 7 reports the marginal effects of the covariates for the full specification. They reveal further insights such as the significant role of decolonization previously mentioned. In particular, having gone through a decolonization border change decreases the probability

\footnotetext{
tive coefficient for the probability of being jus soli.

${ }^{15}$ For all three specifications, we verified that our results are not driven by outliers.

${ }^{16}$ The correlation between Berlin wall and socialist is 0.48 .

${ }^{17}$ For example, no country affected by Berlin wall has ever applied jus soli.
} 
of being jus soli by about 14\%. Moreover, an increase in migration of one percentage point increases the probability of being a jus sanguinis country by about $2.5 \%$, and decreases the probability of having a mixed regime by $2.3 \%$. Besides, an increase in migration of one percentage point for a jus sanguinis country decreases the probability of being jus sanguinis by about $2.7 \%$.

Overall, our results indicate that migration, the original laws and our geopolitical dummies exert a significant impact on current citizenship laws, and that other factors such as government size, demographics and democracy also contribute to their determination. In particular, we show that legal tradition tends to affect the current legislation persistently, even though the process of transplantation can prove discontinuous in the case of former colonies. In addition, we show that a jus sanguinis origin, which is associated with a civil legal origin, is less conducive to adaptation than a jus soli origin. This suggests that different legal traditions tend to be associated with different degrees of flexibility. We also find that high migration has a negative impact on the adoption of jus soli elements, and in particular on the probability of applying a mixed regime. However, the full effect of migration is also determined by the interaction term, which is positive for jus sanguinis countries, suggesting that for these countries migration does cause a shift of the legislation toward a mixed or a jus soli regime. The hypothesis of convergence toward a mix of provisions, suggested by some political theories (see Section 1), finds only partial support in our results. Contrary to our prior, the welfare burden proves not to be an obstacle for a jus soli legislation. However, this could be explained by the fact many of the countries with extended welfare systems may favor immigration because of their demographic crisis. Indeed demographic stagnation encourages the adoption of mixed and jus soli regimes. Moreover, the impact we observe for the size of government could be explained by the fact that it proxies for European-style, relative open socialdemocracies. Finally, the evidence demonstrates that a higher degree of democracy is associated with more jus soli elements, while culture as captured by religious affiliation and ethnolinguistic fractionalization appears to be irrelevant. 


\subsection{Robustness}

In this section we present a number of alternatives to our benchmark regressions to investigate whether they are robust to different specifications, samples and estimation techniques.

\subsubsection{Alternative specifications}

We experiment our multinomial logit specifications with alternative covariates. First, we replace our measure of migration with a range of alternative measures. As outlined above, our migration measure was chosen to minimize a potential endogeneity bias. When we replace our migrations stocks with average migration flows (computed with reference to each subperiod), ${ }^{18}$ the coefficients for migration turns out to be insignificant in all three specifications. This could suggest that migration flows are endogenous with respect to citizenship laws. Further tests involve alternative measures of migration stocks, since a possible concern is that migration stock measured in 1960 for the first subperiod and in 1980 for the second subperiod may not be appropriate to capture all the developments of the subsequent 25 years. Therefore, as possible alternatives, for the first and the second subperiod we select the years 1970 and 1990, respectively, and the 1960-70 and 1980-90 averages, respectively. In the Table Appendix, Table A.1, column (1) presents the full specification with the 1960-70 and 1980-90 averages (average migration stock). With these alternative stock measures, some differences emerge in the coefficients for migration and its interaction with jus sanguinis, with the latter losing significance, while the coefficients for the other regressors are largely unaffected. Since in the postwar period migration has been highly regulated by policy in most receiving countries, and citizenship laws could be viewed as part of migration policy, the simultaneous determination of citizenship laws and migration does represent a serious concern when we enter within-the-period data on migration instead of beginning-of-period data. To sum up, our beginning-of-period migration stocks prove to be the most adequate measures of the role of migration. ${ }^{19}$

\footnotetext{
${ }^{18}$ Migration stocks and flows show a correlation of 0.45 .

${ }^{19}$ We also experiment with a specification entering the migrant stock in 1960 for both subperiods, to account for the potential effect of changes in citizenship laws introduced between 1960 and 1980 on subsequent migration decisions. As previously explained, since changes had been extremely rare before 1960, the migrant
} 
Since jus sanguinis and jus soli are in principle closely linked to the civil and common systems of laws, respectively, the influence of the legal tradition can also be analyzed through a dummy capturing the presence of a civil law tradition (i.e., a dummy equal to 1 if a country belongs to the civil law tradition and equal to 0 if a country belongs to common law). If the coefficients of the two alternative dummies were the same, one could conclude that our detailed codification of the original citizenship laws does not add much to what we can already learn from a country's broader legal tradition. The correlation between the two dummies, however, is only 0.35 , due to the previously illustrated historical events (namely, the early switch to jus soli of civil law Latin America, the introduction of a mixed regime in France and its colonies and, more recently, the jus sanguinis choice of former British colonies). It follows that, when we replace the jus sanguinis with the civil law dummy (see Table A.1, column (2)), the latter turns out to be substantially less significant and reduces the significance of most other regressors. This demonstrates that civil law is a much weaker predictor of current citizenship laws than the original citizenship laws themselves and implies that our citizenship laws classification does contain novel information which is not already embedded in the legal origin data.

We also replace our decolonization dummy with a dummy for British or Portuguese colonies (identifying those countries that were characterized by a jus soli legislation during the colonial period), and with the sub-Saharan Africa dummy. ${ }^{20}$ Both alternatives are associated with insignificant coefficients and marginal effects. This implies that our dummy for a decolonization border change does capture more precisely an important determinant of current citizenship laws.

\subsubsection{Alternative estimation techniques}

Alternative estimation techniques broadly confirm the same results from Table 7 . In particular, an (unreported) alternative multinomial probit model delivers the same qualitative results.

stock in 1960 is not subject to this concern. Results from this instrumented specification are similar to those presented in Table 6 .

${ }^{20}$ Decolonization shows a significant correlation with the dummies for British or Portuguese colony (0.30) and for sub-Saharan Africa (0.31). Regression results are omitted for brevity. 
We also run ordered logit regressions where current citizenship laws are explicitly treated as an ordinal variable, which we assume here to be ordered by increasing inclusiveness, i.e., we assume that jus sanguinis corresponds to minimal and jus soli to maximal inclusiveness. These results are reported in Table A.2 in the Table Appendix. Even though the single coefficient for each covariate that characterizes an ordered logit regression fails to capture some facets of the issues which are more clearly disentangled by the two coefficients of the multinomial logit, overall the previous results are confirmed, with migration and a jus sanguinis origin exerting a negative impact on the application of jus soli.

\subsubsection{Alternative sample criteria}

We also run multinomial logit regressions on a cross-sectional sample composed by country averages over the 1950-2000 period. In this specification the dependent variable is citizenship laws in 2001, while migration stock refers to the year 1960 and jus sanguinis in 1948 is the initial citizenship law. All other covariates are adapted accordingly. Therefore, for instance, the decolonization dummy identifies all decolonization events occurring during the 1950-2000 period, and the size of government is an average over the entire period. The results for this cross section reveal a much lower level of significance for several covariates, in particular for migration and for its interaction with the initial laws. ${ }^{21}$ The same applies to alternative variants with a cross section over each subperiod, i.e., 1950-1975 and 1976-2000. This suggests that our panel includes more information on the determinants of citizenship laws than a simple cross section. An alternative ordered logit regression for the cross section also achieved much weaker results than those found in the panel. ${ }^{22}$

For the same cross section, we also run an ordinary least squares regression with an alternative dependent variable, i.e., our citizenship policy index developed in Section 4, which merges information from both citizenship laws at birth and naturalization, both in 2001 . Migration turns out to be insignificant in these regressions, as it does in a comparable ordinary least squares regression with an indexed version of 2001 citizenship laws as dependent

\footnotetext{
${ }^{21}$ We also experiment with migration stocks in 1970 and 1980, and with average migration flows, with similar results.

${ }^{22}$ We also apply to the above results the Cook's distance method to show that they are not driven by outliers.
} 
variable (see Table A.3 in the Table Appendix). ${ }^{23}$ The same qualitative results arise in an unreported regression with naturalization in 2001 as dependent variable. Again these results may be due to the fact that a single cross section of countries includes less information than our panel.

\section{An alternative approach: The determinants of change in citizenship laws}

We also study citizenship laws evolution using an alternative approach which is able to provide us with additional insights about the issue at end. While specification (1) focuses on current citizenship laws as the dependent variable, we developed an alternative specification which is designed to capture more specifically the determinants of a change in the laws.

\subsection{Empirical specification}

In the alternative specification, the dependent variable is the occurrence of a change in citizenship laws. For our panel, we run a logit model of the following form for its full specification:

$$
D_{i t}=\alpha S_{i t}+\beta M_{i t}+\gamma S_{i t} M_{i t}+\delta P_{t}+\mathbf{Z}_{i t}^{\prime} \boldsymbol{\eta}+\xi_{i t},
$$

where $D_{i t}$ is a dummy variable which is equal to 1 if any change in citizenship laws occurred in country $i$ and period $t$ and is equal to 0 if no change occurred. ${ }^{24}$ The regressors are all the variables previously described and $\xi_{i t}$ is the error term.

Pairwise correlations among our new dependent variable, changes in citizenship laws, and the independent variables are presented in Table 5. The dependent variable is correlated

\footnotetext{
${ }^{23}$ The main difference between the two OLS regressions is that jus sanguinis as initial law becomes insignificant when the dependent variable is the citizenship policy index. This difference is to be attributed to the fact this initial condition does not exactly match the dependent variable, since data on naturalization in 1948 are not available.

${ }^{24}$ While it would be informative to further distinguish between the directions of a change, the dimension of our sample would render this specification problematic.
} 
negatively with a jus sanguinis origin (-0.24) and with the Latin America dummy (-0.22), positively with the decolonization dummy (0.36).

\subsection{Results}

Regression results for the logit models are presented in Table 8. Once again we develop three alternative specifications of increasing complexity. Jus sanguinis as the initial law always exerts a negative impact on change in all three specifications, suggesting that this kind of regime is the most resistant to adaptation. While migration has a positive impact on change in the core version (a), no significant effect survives the inclusion of additional covariates. In version (b), decolonization and Southern Europe appear to exert a positive impact on change, while Latin America resists it. This confirms our previous findings, with added implications. In particular, a decolonization border change - as well as belonging to Southern Europe - tends to induce change, while belonging to Latin America implies resistance. In the full specification, among the additional covariates we find a negative effect on change for the share of young, meaning that relatively old countries are more likely to adapt their legislation, and a positive effect for the period dummy, i.e., change is more likely to occur in the second subperiod.

Overall, these results are complementary to those of Section 5 since they highlight which factors have induced the observed evolution of the legislation. In particular, we have identified a jus sanguinis origin as a factor of resistance to change, while migration has an insignificant impact on adaptation. The latter effect is probably due to the fact that migration has a complex impact on a country's legislation which is not captured by the binary nature of the dependent variable used in these regressions. Decolonization and the wave of legislative reforms recently occurred especially in Southern Europe clearly emerge as the major forces that have contributed to the adaptation of citizenship laws in the postwar period.

\subsection{Robustness}

As for specification (1), we perform a full set of robustness checks for (2). Additional covariates such as per capita income and the Gini index once again fail to add any significance 
to the logit estimates and are therefore omitted from the specification in Table 8. Alternative measures of migration confirm an irrelevant impact on change in the laws.

When we replace the dummy reflecting jus sanguinis as the initial law with the civil law dummy, we find the latter insignificant. Similarly, when we replace our decolonization dummy with the dummy for British or Portuguese colonies, or with the sub-Saharan Africa dummy, both of them are insignificant.

Alternative estimation techniques include a probit version of the model, which delivers results substantially similar to the logit. We also develop parallel sets of fixed and random effects logit regressions. Results appear in Table A.4. With fixed effects, the decolonization dummy remains the only significant determinant of change. With random effects, all the covariates which were found significant in the pooled logit remain significant. In particular, the decolonization, Latin America, and Southern Europe dummies still retain a significant impact on change. ${ }^{25}$

\section{Conclusion}

We studied the determinants and evolution of the legal institution of citizenship around the world in the postwar period, on the basis of a new data set we compiled. We found that citizenship laws have responded endogenously and systematically to a number of economic factors such as migration, the size of government, and demographic trends, as well as to additional political and historical factors such as the legal tradition, the colonial experience, and the degree of democracy. In particular, our data confirm the persistence of legal tradition, with a particularly strong tendency for jus sanguinis to be preserved. The presence of a large stock of migrants has not shaped national legislations in the direction of convergence toward a mixed regime that includes both jus soli and jus sanguinis elements. At the same time, those jus sanguinis countries exposed to large migration have moved toward the adoption of jus soli provisions. Border instability emerges as a decisive factor in shaping citizenship laws, particularly following the decolonization phase, reflecting discontinuities for the transplant-

\footnotetext{
${ }^{25}$ For the sake of comparison, we also run a logit over the cross section, and find that the regression yield results that were similar, even though weaker, than those from the panel.
} 
ing process of legal institutions. Countries with larger welfare systems, older population and more extended political rights tend to be associated with more diffused elements of jus soli.

More generally, a clear implication of our investigation is that institutions should not be presumed to be exogenous, since they do adapt both to economic and non-economic factors. The endogeneity of institutions to economic factors represents a challenge for research aimed at demonstrating that institutions are crucial determinants of economic performances. By showing that citizenship laws are shaped not only by the broader legal origins, but also by other institutions such as the internal system of political rights and the international system of relations as reflected by state borders, we also establish that different institutions are interrelated. This represents another challenge for further research on the process of formation of legal rules and on the impact of institutions on economic outcomes.

Citizenship laws are still changing. Further research could study the future evolution of citizenship policy, by using projections of international migration patterns in combination with the available predictions about the future course of democratization and border changes. Finally, citizenship laws can be viewed as a link, within a legal system, between the public and the private sphere of influence. Many issues that fall within the former - such as commercial law, labor regulation, and government activities - have already been investigated. Our methodology could be extended to the study of other evolving bodies of the law, such as family law, rules of inheritance, and women's rights.

\section{DATA APPENDIX}

\section{A. The citizenship-at-birth classification}

Group 1 (jus sanguinis countries): We include countries where citizenship is passed on to a child based upon at least one of the parents being a citizen of that country, regardless of the child's actual country of birth, and where citizenship is not granted due to birth within the country. In the application of jus sanguinis, countries may differ on some factors, for example on the father's vs. mother's right to transmit citizenship by descent, the requirement of citizenship for one or both parents, the relevance of the marital status of the parents. Most of these factors depend on the interaction between local family law and 
citizenship law. A common exception to the general principle of jus sanguinis is automatic citizenship attribution to children of unknown parents. Since we focus on the presence of jus soli elements in a country's legislation, our classification does not emphasize how narrowly jus sanguinis can be specifically applied to emigrants. Examples of restrictions are generational requirements limiting the principle of citizenship by descent to the first or second generations of individuals born and residing abroad, residence requirements for parents, and the requirement that parents must be citizens other than by descent.

Group 2 (countries with a mixed regime): We include those countries where elements of jus soli are recognized, albeit in a restrictive form, and coexist with varying degrees of jus sanguinis. For example, a frequent provision that limits jus soli is double jus soli (i.e., automatic citizenship for the children of those immigrants who were also born in the country). Another is the ability, for a child born in a country were jus sanguinis prevails, to acquire citizenship at some later point (e.g., the age of maturity) subject to either residence requirements or application. Moreover, we interpret as an element of jus soli, that justifies the inclusion of a country within Group 2, the existence of a provision that birth in the country matters for naturalization.

Group 3 (jus soli countries): We include those countries where citizenship is automatically granted due to birth within the country, regardless of the parents' citizenship or status. Normally countries that apply jus soli combine it with jus sanguinis provisions for the children of their citizens born outside of their territory (although limitations to the ability to transmit citizenship acquired in this manner to the next generation usually apply through, for example, residence requirements).

\section{B. The border change dummies}

We construct three border change dummies (i.e. Decolonization, Berlin Wall, and Other Border Changes) based on data collected from Polity IV (2002). In particular, from the Polity IV variable CHANGE we record information on four types of events capable of affecting state borders, i.e. State Disintegration, State Transformation, State Demise, and State Creation. Even if we set 1948 as the initial date for our citizenship laws analysis, for border changes we include a few earlier events occurred in the 1943-1948 period that fit within the phase of postcolonial independence. Examples of the events contained in the Polity IV (2002) data set are 
the State Disintegration of Yugoslavia in 1991; the State Transformation of Germany in 1990, East Germany in 1945, West Germany in 1945, and Russia in 1992); the State Demise of Germany in 1945, East Germany in 1990, West Germany in 1990, and the USSR in 1991. The countries affected by State Creation are the most numerous. They include the new countries gaining independence - and therefore state borders - in the postwar decolonization phase, the new countries formed in Europe after the fall of the Berlin wall, plus a few additional observations not linked to these two waves. Clearly, there is substantial overlap among the observations recorded in the Polity IV data set. We adapt these data to our needs by matching them to the 162 countries appearing in our citizenship laws data set. For instance, we count as a single event, occurring to Germany, the State Transformation of East and West Germany in 1945, but also the State Demise of Germany in the same year. Likewise, we treat as another single event, occurring again to Germany, the State Transformation of Germany in 1990 and the State Demise of East and West Germany in the same year. On the other hand, the separation of Bangladesh from Pakistan counts for two events, because it concerns two countries which are in our sample. Additional information, when necessary, was obtained from the CIA (2002). On this basis, we construct our three border change dummies for each period under consideration: Decolonization (identifying countries which went through a postcolonial redefinition of their borders), Berlin wall (identifying countries which went through a post-1989 Berlin wall border change), and other border changes (identifying countries which went through other types of boundary changes, of which examples are the split between Pakistan and Bangladesh, and the unification of Vietnam). To be noticed is that the way our variables are coded reflects stability of borders, i.e., the absence of border changes, more than the direction of a change in terms of a country's size.

\section{Definitions and sources of other covariates}

Migration stock: International migration stock (\% population). Migration stock is the number of people born in a country other than that in which they live, including refugees. The data are taken from United Nations (2003) and are available for 1960, 1970, 1980, 1990 and 2000. Net migration flows: International net migration rate. The data refer to incoming international migrants less outgoing international migrants, per 1,000 total population. The source is the United Nations (2005). The data are available over five year 
intervals from 1950, with projections until 2050. Civil law: The source is the legal origin classification in La Porta et al. (1999). We retain only the two main families of common and civil law, without distinguishing, within the broader civil law tradition, among the French, German, and Scandinavian versions, since they do not present any significant difference for the issue of citizenship. Moreover, while La Porta et al. (1999) introduce a separate class for socialist-law countries, we assign them to their own class of common or civil law as it prevailed before the communist period. Latin America, Southern Europe and subSaharan Africa: Dummies for countries belonging to Latin America, Southern Europe and sub-Saharan Africa. The classification is from UN (2002). British or Portuguese colony: Dummy for countries that were British or Portuguese colonies any time after 1918. The source is the "Correlates of War 2 Project" (2004). Small country: Dummy for countries with a population size of less than one million over all available years between 1960 and 1995, as in Easterly and Kraay (2000). Socialist: Dummy for socialist countries. Information is from La Porta et al. (1999). Oil: Dummy for oil countries (OPEC countries plus Oman, Angola, Qatar, Bahrain, and Brunei). Government consumption: Government share of GDP in current prices, taken from Penn World Tables (2002). Share of young: Share of young between age 15 and 34 (\% population). The data are taken from United Nations (2005). Ethnolinguistic fractionalization: Composite index of ethnolinguistic fractionalization, taken from Easterly and Levine (1997). Catholic share: Percentage of Catholics in 1980, taken from La Porta et al. (1999). Political rights: Political rights index, taken from Freedom House (1996). GDP per capita: Logarithm of real GDP per capita at current international prices, taken from Penn World Tables (2002). Gini index: Gini index of inequality, taken from Deininger and Squire (1996).

\section{REFERENCES}

Acemoglu, D. , Johnson, S. and Robinson, J.A., 2001, The Colonial Origins of Comparative Development: An Empirical Investigation, American Economic Review 91, 1369-1401.

Aleinikoff, T. A. and Klusmeyer, D. (eds.), 2001, Citizenship Today: Global Perspectives and Practices, Carnegie Endowment for International Peace, Washington. 
Aleinikoff, T. A. and Klusmeyer, D. (eds.), 2000, From Migrants to Citizens: Membership in a Changing World, Carnegie Endowment for International Peace, Washington.

Alesina, A. and Spolaore, E., 1997, On the Number and Size of Nations, Quarterly Journal of Economics 112, 1027-1056.

Benhabib, J., 1996, On the Political Economy of Migration, European Economic Review 40, $1737-1744$.

Bertocchi, G. and Strozzi, C., 2006, The Age of Mass Migration: Economic and Institutional Determinants, mimeo, University of Modena.

Bolton, P. and Roland, G., 1997, The Breakup of Nations: A Political Economy Analysis, Quarterly Journal of Economics 112, 1057-1090.

Brubaker, R., 1992, Citizenship and Nationhood in France and Germany, Harvard University Press, Cambridge.

Central Intelligence Agency, The World Factbook 2002, CIA, Washington.

Correlates of War 2 Project, 2004, Department of Political Science, The Pennsylvania State University.

Deininger, K. and Squire, L., 1996, A New Data Set Measuring Income Inequality, The World Bank Economic Review 10, 565-91.

DeVoretz, D.J., 2006, Immigration Policy: Methods of Economic Assessment, International Migration Review 40, 390-418.

DeVoretz, D.J. and Pivnenko, S., 2006, The Economic Causes and Consequences of Canadian Citizenship, Journal of Immigration and Integration 6, 435-468.

Easterly, W. and Kraay, A., 2000, Small States, Small Problems? Income, Growth, and Volatility in Small States, World Development 28, 2013-2027.

Easterly, W. and Levine, R., 1997, Africa's Growth Tragedy: Policies and Ethnic Divisions, Quarterly Journal of Economics 112, 1203-1250. 
Engerman, S. L. and Sokoloff, K.L., 2002, Factor Endowment, Inequality, and Paths of Development Among New World Economies, NBER Working Paper 9259.

Freedom House, 1996, Freedom in the World. Political Rights and Civil Liberties, Freedom House, New York.

Gradstein, M. and Schiff, M., 2006, The Political Economy of Social Exclusion with Implications for Immigration Policy, Journal of Population Economics 19, 327-44.

Hatton, T.J. and Williamson, J.G., 2006, International Migration in the Long Run: Positive Selection, Negative Selection and Policy, in Foders, F. and Langhammer, R.J. (eds.), Labor Mobility and the World Economy, Springer, Heidelberg.

Heston, A., Summers, R. and Aten, B., 2002, Penn World Table Version 6.1, Center for International Comparisons at the University of Pennsylvania (CICUP), October.

Huntington, S.P., 2004, Who Are We: The Challenges to America's National Identity, Simon \& Schuster, New York.

Joppke, C. (ed.), 1998, Challenge to the Nation-State: Immigration in Western Europe and the United States, Oxford University Press, Oxford.

La Porta, R., Lopez-de-Silanes, F., Shleifer, A. and Vishny, R.W., 1999, The Quality of Government, Journal of Law, Economics and Organization 15, 222-279.

La Porta, R., Lopes-de-Silanes, F., Shleifer, A. and Vihny, R.W., 1998, Law and Finance, Journal of Political Economy 106, 1113-1155.

Mayda, A.M., 2005, Who is Against Immigration? A Cross-country Investigation of Individual Attitudes towards Immigration, Review of Economics and Statistics, forthcoming.

O'Rourke, K.H. and Sinnott, R., 2005, The Determinants of Individual Attitudes towards Immigration, European Journal of Political Economy, forthcoming.

Polity IV, 2002, Political Regime Characteristics and Transitions, 1800-2002, Center for International Development and Conflict Management, University of Maryland. 
Pritchett, L., 2006, Let Their People Come: Breaking the Deadlock in International Labor Mobility, The Brookings Institution Press, Washington.

Razin, A., Sadka, E. and Swagel, P., 2002, Tax Burden and Migration: A Political Economy Theory and Evidence, Journal of Public Economics 85, 167-190.

Timmer, A. and Williamson, J.G., 1998, Immigration Policy Prior to the Thirties: Labor Markets, Policy Interaction, and Globalization Backlash, Population and Development Review 24, 739-771.

UN, 2005, World Population Prospects: Population Estimates and Projections, United Nations, New York.

UN, 2003, Trends in Total Migrant Stock: The 2003 Revision, United Nations, New York.

UN Common Database, 2002, United Nations, New York.

UN High Commissioner for Refugees, Country of Origin and Legal Information, 2003, United Nations, Geneva.

United States Office of Personnel Management, Investigations Service, Citizenship Laws of the World, 2001.

Weil, P., 2001, Access to Citizenship: A Comparison of Twenty-Five Nationality Laws, in Aleinikoff, T. A. and Klusmeyer, D. (eds.), Citizenship Today: Global Perspectives and Practices, 17-35, Carnegie Endowment for International Peace, Washington. 
Table 1

Citizenship Laws Evolution: Transition Matrices

\begin{tabular}{|c|c|c|c|c|}
\hline & \multicolumn{3}{|c|}{ Citizenship laws in 2001} & \multirow[b]{2}{*}{ Total } \\
\hline Citizenship laws in 1948 & $\begin{array}{l}\text { Jus sanguinis } \\
\text { regime }\end{array}$ & $\begin{array}{l}\text { Mixed } \\
\text { regime }\end{array}$ & $\begin{array}{l}\text { Jus soli } \\
\text { regime }\end{array}$ & \\
\hline Jus sanguinis regime & 46 & 20 & 1 & 67 \\
\hline Mixed regime & 11 & 6 & 2 & 19 \\
\hline Jus soli regime & 31 & 9 & 36 & 76 \\
\hline \multirow[t]{2}{*}{ Total } & 88 & 35 & 39 & 162 \\
\hline & \multicolumn{3}{|c|}{ Citizenship laws in 1975} & \\
\hline Citizenship laws in 1948 & $\begin{array}{l}\text { Jus sanguinis } \\
\text { regime }\end{array}$ & $\begin{array}{l}\text { Mixed } \\
\text { regime }\end{array}$ & $\begin{array}{l}\text { Jus soli } \\
\text { regime }\end{array}$ & Total \\
\hline Jus sanguinis regime & 63 & 3 & 1 & 67 \\
\hline Mixed regime & 10 & 7 & 2 & 19 \\
\hline Jus soli regime & 28 & 1 & 47 & 76 \\
\hline \multirow{2}{*}{ Total } & 101 & 11 & 50 & 162 \\
\hline & \multicolumn{3}{|c|}{ Citizenship laws in 2001} & \\
\hline Citizenship laws in 1975 & $\begin{array}{l}\text { Jus sanguinis } \\
\text { regime }\end{array}$ & $\begin{array}{l}\text { Mixed } \\
\text { regime }\end{array}$ & $\begin{array}{l}\text { Jus soli } \\
\text { regime }\end{array}$ & Total \\
\hline Jus sanguinis regime & 81 & 20 & 0 & 101 \\
\hline Mixed regime & 2 & 9 & 0 & 11 \\
\hline Jus soli regime & 5 & 6 & 39 & 50 \\
\hline Total & 88 & 35 & 39 & 162 \\
\hline
\end{tabular}

Table 2

Changes in Citizenship Laws

\begin{tabular}{|c|c|c|c|}
\hline & \multicolumn{2}{|c|}{ Changes in citizenship laws (1948 to 2001) } & \\
\hline Citizenship laws in 1948 & No change & Change & Total \\
\hline Jus sanguinis regime & 46 & 21 & 67 \\
Mixed regime & 6 & 13 & 19 \\
Jus soli regime & 36 & 40 & 76 \\
\hline Total & 88 & 74 & 162 \\
\hline Citizenship laws in 1948 & \multicolumn{2}{|c|}{ Changes in citizenship laws (1948 to 1975) } & \\
\hline Jus sanguinis regime & No change & Change & Total \\
Mixed regime & 63 & 4 & 67 \\
Jus soli regime & 7 & 12 & 19 \\
\hline Total & 47 & 29 & 76 \\
\hline & 117 & 45 & 162 \\
\hline Citizenship laws in 1975 & Changes in citizenship laws (1975 to 2001) & \\
\hline Jus sanguinis regime & 81 & Change & Total \\
Mixed regime & 9 & 20 & 101 \\
Jus soli regime & 39 & 2 & 11 \\
\hline Total & 129 & 11 & 162 \\
\hline
\end{tabular}


Table 3

Citizenship Laws Data Set: Summary Statistics

\begin{tabular}{|l|c|c|c|c|c|}
\hline Variable & Obs. & Mean & Std. Dev. & Min. & Max. \\
\hline Citizenship laws in 2001 & 162 & 1.698 & 0.835 & 1 & 3 \\
\hline Citizenship laws in 1975 & 162 & 1.685 & 0.916 & 1 & 3 \\
\hline Citizenship laws in 1948 & 162 & 2.056 & 0.941 & 1 & 3 \\
\hline Changes in citizenship laws (1948 to 2001) & 162 & 0.457 & 0.500 & 0 & 1 \\
\hline Naturalization in 2001 & 142 & 2.458 & 0.920 & 1 & 4 \\
\hline Citizenship policy index in 2001 & 142 & 0.442 & 0.272 & 0 & 1 \\
\hline
\end{tabular}

Table 4

Summary Statistics, 1950-2000

\begin{tabular}{|l|c|c|c|c|c|}
\hline Variable & Obs. & Mean & Std. Dev. & Min. & Max. \\
\hline Current citizenship laws & 324 & 1.691 & 0.875 & 1 & 3 \\
\hline Changes in citizenship laws & 324 & 0.241 & 0.428 & 0 & 1 \\
\hline Jus sanguinis as initial citizenship law & 324 & 0.519 & 0.500 & 0 & 1 \\
\hline Civil legal origin & 324 & 0.673 & 0.470 & 0 & 1 \\
\hline Migration stock & 300 & 5.646 & 9.713 & 0.011 & 70.673 \\
\hline Net migration flows & 318 & -0.116 & 8.551 & -47.95 & 63.35 \\
\hline Decolonization & 324 & 0.250 & 0.434 & 0 & 1 \\
\hline Berlin wall & 324 & 0.052 & 0.223 & 0 & 1 \\
\hline Other border changes & 324 & 0.022 & 0.146 & 0 & 1 \\
\hline Latin America & 324 & 0.173 & 0.379 & 0 & 1 \\
\hline Southern Europe & 324 & 0.043 & 0.204 & 0 & 1 \\
\hline Small country & 324 & 0.160 & 0.368 & 0 & 1 \\
\hline Sub-Saharan Africa & 324 & 0.265 & 0.442 & 0 & 1 \\
\hline British or Portuguese colony & 324 & 0.333 & 0.472 & 0 & 1 \\
\hline Socialist & 324 & 0.173 & 0.379 & 0 & 1 \\
\hline Oil & 324 & 0.086 & 0.281 & 0 & 1 \\
\hline Political rights & 276 & 3.730 & 2.040 & 1 & 7 \\
\hline Catholic share & 324 & 31.535 & 35.572 & 0 & 97.3 \\
\hline Ethnolinguistic fractionalization & 272 & 0.349 & 0.299 & 0 & 0.890 \\
\hline Government consumption & 263 & 19.617 & 11.342 & 2.492 & 72.233 \\
\hline Share of young & 324 & 34.54 & 3.47 & 27.01 & 53.36 \\
\hline Log GDP per capita & 263 & 7.488 & 1.249 & 4.979 & 10.060 \\
\hline Gini index & 155 & 40.425 & 9.966 & 20.495 & 63.180 \\
\hline
\end{tabular}

${ }^{\S}$ The sample includes two cross sections of 162 countries. The first cross section refers to the 1950-1975 subperiod while the second cross section refers to the 1976-2000 subperiod. For details about the construction of the variables see the text. 
Table 5

Pairwise Correlations Among Dependent and Independent Variables, 1950-2000

\begin{tabular}{|l|c|c|}
\hline & Citizenship laws & Changes in citizenship laws \\
\hline Migration stock & $-0.12^{* *}$ & 0.08 \\
Net migration flows & $-0.11^{*}$ & -0.03 \\
Jus sanguinis as initial citizenship law & $-0.64^{* * *}$ & $-0.24^{* * *}$ \\
Civil legal origin & $-0.15^{* * *}$ & $-0.15^{* * *}$ \\
Decolonization & -0.09 & $0.36^{* * *}$ \\
Berlin wall & -0.08 & $0.09^{*}$ \\
Other border changes & -0.07 & -0.03 \\
Latin America & $0.60^{* * *}$ & $-0.22^{* * *}$ \\
Southern Europe & -0.05 & $0.09^{*}$ \\
Small country & $0.14^{* *}$ & 0.05 \\
Sub-Saharan Africa & $-0.12^{* *}$ & $0.15^{* * *}$ \\
British or Portuguese colony & 0.02 & $0.15^{* * *}$ \\
Socialist & $-0.25^{* * *}$ & $-0.10^{*}$ \\
Oil & $-0.13^{* *}$ & 0.01 \\
Political rights & $0.29^{* * *}$ & 0.05 \\
Catholic share & $0.39^{* * *}$ & -0.07 \\
Ethnolinguistic fractionalization & $-0.10^{*}$ & $0.17^{* * *}$ \\
Government consumption & -0.03 & -0.05 \\
Share of young & -0.03 & $-0.13^{* *}$ \\
Log GDP per capita & 0.05 & -0.03 \\
Gini Index & $0.22^{* * *}$ & -0.09 \\
\hline
\end{tabular}

$\S$ The sample includes two cross sections of 162 countries. The first cross section refers to the 1950-1975 subperiod while the second cross section refers to the 1976-2000 subperiod. For details about the construction of the variables see the text.

$*$ significant at $10 \% ; * *$ significant at $5 \% ; * * *$ significant at $1 \%$ 
Table 6

The Determinants of Citizenship Laws: Multinomial Logit Estimates, 1950-2000

\begin{tabular}{|c|c|c|c|c|c|c|}
\hline & \multicolumn{2}{|c|}{ (a) } & \multicolumn{2}{|c|}{ (b) } & \multicolumn{2}{|c|}{ (c) } \\
\hline & $\begin{array}{l}\text { Mixed } \\
\text { regime }\end{array}$ & $\begin{array}{l}\text { Jus soli } \\
\text { regime }\end{array}$ & $\begin{array}{l}\text { Mixed } \\
\text { regime }\end{array}$ & $\begin{array}{l}\text { Jus soli } \\
\text { regime }\end{array}$ & $\begin{array}{l}\text { Mixed } \\
\text { regime }\end{array}$ & $\begin{array}{l}\text { Jus soli } \\
\text { regime }\end{array}$ \\
\hline Migration stock & \begin{tabular}{|l}
-0.051 \\
{$[-1.86]^{*}$}
\end{tabular} & $\begin{array}{l}-0.055 \\
{[-2.81]^{* * *}}\end{array}$ & \begin{tabular}{|l|}
-0.054 \\
{$[-1.79]^{*}$}
\end{tabular} & $\begin{array}{l}-0.032 \\
{[-1.61]}\end{array}$ & $\begin{array}{l}-0.167 \\
{[-2.30]^{* *}}\end{array}$ & $\begin{array}{l}-0.045 \\
{[-1.53]}\end{array}$ \\
\hline Jus sang. as init. cit. law & $\begin{array}{l}-2.044 \\
{[-4.39]^{* * *}}\end{array}$ & $\begin{array}{l}-6.048 \\
{[-5.43]^{* * *}}\end{array}$ & $\begin{array}{l}-2.712 \\
{[-4.99] * * *}\end{array}$ & $\begin{array}{l}-6.117 \\
{[-4.90]^{* * *}}\end{array}$ & $\begin{array}{l}-4.568 \\
{[-5.24] * * *}\end{array}$ & $\begin{array}{l}-7.59 \\
{[-4.38]^{* * *}}\end{array}$ \\
\hline Period & $\begin{array}{l}1.887 \\
{[4.28] * * *}\end{array}$ & $\begin{array}{l}1.193 \\
{[3.02]^{* * *}}\end{array}$ & $\begin{array}{l}1.409 \\
{[2.28]^{* *}}\end{array}$ & $\begin{array}{l}-0.272 \\
{[-0.47]}\end{array}$ & $\begin{array}{l}2.385 \\
{[2.65] * * *}\end{array}$ & $\begin{array}{l}0.211 \\
{[0.27]}\end{array}$ \\
\hline Decolonization & & & $\begin{array}{l}-1.296 \\
{[-1.87]^{*}}\end{array}$ & $\begin{array}{l}-2.211 \\
{[-3.41]^{* * *}}\end{array}$ & {$\left[\begin{array}{l}-0.084 \\
{[-0.09]}\end{array}\right.$} & $\begin{array}{l}-1.523 \\
{[-1.55]}\end{array}$ \\
\hline Southern Europe & & & $\begin{array}{l}1.224 \\
{[2.03]^{* *}}\end{array}$ & $\begin{array}{l}-0.153 \\
{[-0.14]}\end{array}$ & $\begin{array}{l}1.234 \\
{[1.69]^{*}}\end{array}$ & $\begin{array}{l}1.187 \\
{[0.87]}\end{array}$ \\
\hline Latin America & & & {$\left[\begin{array}{l}-0.799 \\
{[-0.70]}\end{array}\right.$} & $\begin{array}{l}2.866 \\
{[3.73]^{* * *}}\end{array}$ & $\begin{array}{l}-0.621 \\
{[-0.51]}\end{array}$ & $\begin{array}{l}4.495 \\
{[2.93]^{* * *}}\end{array}$ \\
\hline Small country & & & $\begin{array}{l}-0.804 \\
{[-1.23]}\end{array}$ & $\begin{array}{l}0.415 \\
{[0.69]}\end{array}$ & $\begin{array}{l}-2.566 \\
{[-1.88]^{*}}\end{array}$ & $\begin{array}{l}0.523 \\
{[0.64]}\end{array}$ \\
\hline Jus san. $\mathrm{X}$ migration stock & & & & & $\begin{array}{l}0.156 \\
{[1.81]^{*}}\end{array}$ & $\begin{array}{l}0.084 \\
{[1.75]^{*}}\end{array}$ \\
\hline Government consumption & & & & & $\begin{array}{l}0.035 \\
{[1.07]}\end{array}$ & $\begin{array}{l}0.063 \\
{[2.68]^{* * *}}\end{array}$ \\
\hline Share of young & & & & & $\begin{array}{l}-0.193 \\
{[-1.75]^{*}}\end{array}$ & $\begin{array}{l}-0.397 \\
{[-2.43]^{* *}}\end{array}$ \\
\hline Catholic share & & & & & $\begin{array}{l}0.012 \\
{[1.46]}\end{array}$ & $\begin{array}{l}0.01 \\
{[0.70]}\end{array}$ \\
\hline Ethno. fractionalization & & & & & $\begin{array}{l}0.023 \\
{[0.02]}\end{array}$ & $\begin{array}{l}1.277 \\
{[1.02]}\end{array}$ \\
\hline Political rights & & & & & $\begin{array}{l}0.548 \\
{[2.84] * * *}\end{array}$ & $\begin{array}{l}0.426 \\
{[2.46]^{* *}}\end{array}$ \\
\hline Constant & $\begin{array}{l}-1.092 \\
{[-2.73]^{* * *}}\end{array}$ & $\begin{array}{l}0.626 \\
{[2.48]^{* *}}\end{array}$ & $\begin{array}{l}-0.024 \\
{[-0.03]}\end{array}$ & $\begin{array}{l}1.353 \\
{[2.43]^{* *}}\end{array}$ & $\begin{array}{l}3.716 \\
{[1.05]}\end{array}$ & $\begin{array}{l}11.165 \\
{[2.09]^{* *}}\end{array}$ \\
\hline Observations & 300 & 300 & 300 & 300 & 224 & 224 \\
\hline Log likelihood & -195.77 & & -155.94 & & -95.24 & \\
\hline Maximum Likelihood R2 & 0.45 & & 0.58 & & 0.68 & \\
\hline McFadden's R2 & 0.32 & & 0.46 & & 0.57 & \\
\hline McFadden's Adj R2 & 0.29 & & 0.4 & & 0.44 & \\
\hline Cragg \& Uhler's R2 & 0.53 & & 0.68 & & 0.79 & \\
\hline Count R2 & 0.71 & & 0.81 & & 0.83 & \\
\hline Adj Count R2 & 0.32 & & 0.55 & & 0.64 & \\
\hline
\end{tabular}

${ }^{\S}$ Jus sanguinis is the reference category. Robust $\mathrm{z}$ statistics in brackets, clustered at country level.

* significant at $10 \% ; *$ significant at $5 \% ; * *$ significant at $1 \%$ 
Table 7

Marginal Effects for Multinomial Logit Estimates, 1950-2000, Full Specification ${ }^{\S}$

\begin{tabular}{|c|c|c|c|}
\hline & Jus sanguinis regime & Mixed regime & Jus soli regime \\
\hline Migration stock & $\begin{array}{l}0.025 \\
{[0.010]^{* *}}\end{array}$ & \begin{tabular}{|l|}
-0.023 \\
{$[0.011]^{* *}$}
\end{tabular} & \begin{tabular}{|l|}
-0.001 \\
{$[0.004]$}
\end{tabular} \\
\hline Jus sanguinis as initial cit. law & $\begin{array}{l}0.875 \\
{[0.047]^{* * *}}\end{array}$ & $\begin{array}{l}-0.193 \\
{[0.075]^{* *}}\end{array}$ & $\begin{array}{l}-0.681 \\
{[0.086]^{* * *}}\end{array}$ \\
\hline Period & $\begin{array}{l}-0.303 \\
{[0.155]^{*}}\end{array}$ & $\begin{array}{l}0.336 \\
{[0.117]^{* * *}}\end{array}$ & {$\left[\begin{array}{l}-0.034 \\
{[0.077]}\end{array}\right.$} \\
\hline Decolonization & $\begin{array}{l}0.123 \\
{[0.155]}\end{array}$ & $\begin{array}{l}0.016 \\
{[0.125]}\end{array}$ & $\begin{array}{l}-0.139 \\
{[0.079] *}\end{array}$ \\
\hline Southern Europe & $\begin{array}{l}-0.291 \\
{[0.193]}\end{array}$ & $\begin{array}{l}0.170 \\
{[0.166]}\end{array}$ & $\begin{array}{l}0.121 \\
{[0.236]}\end{array}$ \\
\hline Latin America & $\begin{array}{l}-0.611 \\
{[0.147]^{* * *}}\end{array}$ & $\begin{array}{l}-0.194 \\
{[0.068]^{* * *}}\end{array}$ & $\begin{array}{l}0.805 \\
{[0.140]^{* * *}}\end{array}$ \\
\hline Small country & $\begin{array}{l}0.088 \\
{[0.149]}\end{array}$ & $\begin{array}{l}-0.203 \\
{[0.064]^{* * *}}\end{array}$ & $\begin{array}{l}0.114 \\
{[0.133]}\end{array}$ \\
\hline Jus sanguinis $\mathrm{X}$ migration stock & $\begin{array}{l}-0.027 \\
{[0.011]^{* *}}\end{array}$ & $\begin{array}{l}0.021 \\
{[0.014]}\end{array}$ & $\begin{array}{l}0.006 \\
{[0.007]}\end{array}$ \\
\hline Government consumption & $\begin{array}{l}-0.010 \\
{[0.005]^{* *}}\end{array}$ & $\begin{array}{l}0.004 \\
{[0.005]}\end{array}$ & $\begin{array}{l}0.007 \\
{[0.003]^{* *}}\end{array}$ \\
\hline Share of young & $\begin{array}{l}0.061 \\
{[0.023]^{* * *}}\end{array}$ & $\begin{array}{l}-0.018 \\
{[0.016]}\end{array}$ & $\begin{array}{l}-0.043 \\
{[0.020]^{* *}}\end{array}$ \\
\hline Catholic share & \begin{tabular}{|l}
-0.002 \\
{$[0.002]$}
\end{tabular} & $\begin{array}{l}0.001 \\
{[0.001]}\end{array}$ & $\begin{array}{l}0.001 \\
{[0.002]}\end{array}$ \\
\hline Ethno. fractionalization & $\begin{array}{l}-0.124 \\
{[0.219]}\end{array}$ & $\begin{array}{l}-0.028 \\
{[0.171]}\end{array}$ & $\begin{array}{l}0.152 \\
{[0.159]}\end{array}$ \\
\hline Political rights & $\begin{array}{l}-0.107 \\
{[0.031]^{* * *}}\end{array}$ & $\begin{array}{l}0.069 \\
{[0.027]^{* * *}}\end{array}$ & $\begin{array}{l}0.037 \\
{[0.02]^{*}}\end{array}$ \\
\hline
\end{tabular}

$\S$ The full specification refers to specification (c) in Table 6. Robust standard errors in brackets.

$*$ significant at $10 \% ; * *$ significant at $5 \% ; * * *$ significant at $1 \%$ 
Table 8

The Determinants of Change in Citizenship Laws: Logit Estimates (pooled), 1950-2000

\begin{tabular}{|c|c|c|c|}
\hline & (a) & (b) & (c) \\
\hline & $\begin{array}{l}\text { Changes in } \\
\text { citiz. laws }\end{array}$ & $\begin{array}{l}\text { Changes in } \\
\text { citiz. laws }\end{array}$ & $\begin{array}{l}\text { Changes in } \\
\text { citiz. laws }\end{array}$ \\
\hline Migration stock & $\begin{array}{l}0.021 \\
{[1.89]^{*}}\end{array}$ & $\begin{array}{l}0.014 \\
{[1.18]}\end{array}$ & \begin{tabular}{|l|}
0.031 \\
{$[1.08]$}
\end{tabular} \\
\hline Jus sanguinis as initial citizenship law & $\begin{array}{l}-1.182 \\
{[-4.04]^{* * *}}\end{array}$ & $\begin{array}{l}-1.672 \\
{[-4.62]^{* * *}}\end{array}$ & $\begin{array}{l}-1.133 \\
{[-2.14]^{* *}}\end{array}$ \\
\hline Period & $\begin{array}{l}-0.417 \\
{[-1.46]}\end{array}$ & $\begin{array}{l}0.763 \\
{[1.60]}\end{array}$ & $\begin{array}{l}1.466 \\
{[1.84]^{*}}\end{array}$ \\
\hline Decolonization & & $\begin{array}{l}1.798 \\
{[3.82]^{* * *}}\end{array}$ & $\begin{array}{l}2.677 \\
{[3.06]^{* * *}}\end{array}$ \\
\hline Southern Europe & & $\begin{array}{l}1.968 \\
{[3.18]^{* * *}}\end{array}$ & $\begin{array}{l}1.943 \\
{[3.75]^{* * *}}\end{array}$ \\
\hline Latin America & & $\begin{array}{l}-2.731 \\
{[-3.45]^{* * *}}\end{array}$ & $\begin{array}{l}-2.356 \\
{[-2.29]^{* *}}\end{array}$ \\
\hline Small country & & $\begin{array}{l}-0.135 \\
{[-0.33]}\end{array}$ & {$\left[\begin{array}{l}-0.636 \\
{[-0.98]}\end{array}\right.$} \\
\hline Jus sanguinis $\mathrm{X}$ migration stock & & & {$\left[\begin{array}{l}-0.017 \\
{[-0.35]}\end{array}\right.$} \\
\hline Government consumption & & & {$\left[\begin{array}{l}-0.023 \\
{[-1.24]}\end{array}\right.$} \\
\hline Share of young & & & $\begin{array}{l}-0.199 \\
{[-1.77]^{*}}\end{array}$ \\
\hline Catholic share & & & 0.000 \\
\hline Ethnolinguistic fractionalization & & & $\begin{array}{l}1.227 \\
{[1.46]}\end{array}$ \\
\hline Political rights & & & $\begin{array}{l}0.112 \\
{[0.95]}\end{array}$ \\
\hline Constant & \begin{tabular}{|l}
-0.596 \\
{$[-2.74]^{* * * *}$}
\end{tabular} & $\begin{array}{l}-1.326 \\
{[-2.88]^{* * *}}\end{array}$ & $\begin{array}{l}3.844 \\
{[1.04]}\end{array}$ \\
\hline Observations & 300 & 300 & 224 \\
\hline Log likelihood & -154.7 & -124.25 & -85.05 \\
\hline Maximum Likelihood R2 & 0.08 & 0.25 & 0.27 \\
\hline McFadden's R2 & 0.07 & 0.25 & 0.29 \\
\hline McFadden's Adj R2 & 0.05 & 0.21 & 0.18 \\
\hline Cragg \& Uhler's R2 & 0.11 & 0.37 & 0.41 \\
\hline Count R2 & 0.77 & 0.85 & 0.85 \\
\hline Adj Count R2 & 0.04 & 0.37 & 0.33 \\
\hline
\end{tabular}

\&obust $\mathrm{z}$ statistics in brackets, clustered at country level.

* significant at $10 \% ; * *$ significant at $5 \% ; * * *$ significant at $1 \%$ 
TABLE APPENDIX

Table A.1

The Determinants of Citizenship Laws: Multinomial Logit Estimates, 1950-2000 Alternative Covariates

\begin{tabular}{|c|c|c|c|c|}
\hline & \multicolumn{2}{|c|}{ (1) } & \multicolumn{2}{|c|}{ (2) } \\
\hline & $\begin{array}{l}\text { Mixed } \\
\text { regime }\end{array}$ & $\begin{array}{l}\text { Jus soli } \\
\text { regime }\end{array}$ & $\begin{array}{l}\text { Mixed } \\
\text { regime }\end{array}$ & $\begin{array}{l}\text { Jus soli } \\
\text { regime }\end{array}$ \\
\hline Migration stock & & & $\begin{array}{l}-0.056 \\
{[-0.81]}\end{array}$ & $\begin{array}{l}-0.013 \\
{[-0.36]}\end{array}$ \\
\hline Average migration stock & $\begin{array}{l}-0.152 \\
{[-2.12]^{* *}}\end{array}$ & \begin{tabular}{|l}
-0.052 \\
{$[-1.62]$}
\end{tabular} & & \\
\hline Jus sanguinis as initial citizenship law & $\begin{array}{l}-4.533 \\
{[-5.09]^{* * *}}\end{array}$ & $\begin{array}{l}-7.344 \\
{[-4.12] * * *}\end{array}$ & & \\
\hline Civil legal origin & & & $\begin{array}{l}0.941 \\
{[1.21]}\end{array}$ & $\begin{array}{l}-1.742 \\
{[-1.88]^{*}}\end{array}$ \\
\hline Period & $\begin{array}{l}2.397 \\
{[2.68]^{* * *}}\end{array}$ & $\begin{array}{l}0.260 \\
{[0.33]}\end{array}$ & $\begin{array}{l}1.834 \\
{[2.84]^{* * *}}\end{array}$ & $\begin{array}{l}-0.649 \\
{[-1.31]}\end{array}$ \\
\hline Decolonization & {$\left[\begin{array}{l}-0.140 \\
{[-0.16]}\end{array}\right.$} & $\begin{array}{l}-1.525 \\
{[-1.54]}\end{array}$ & $\begin{array}{l}1.509 \\
{[1.79]^{*}}\end{array}$ & $\begin{array}{l}-0.003 \\
{[-0.01]}\end{array}$ \\
\hline Southern Europe & $\begin{array}{l}1.218 \\
{[1.64]}\end{array}$ & $\begin{array}{l}1.062 \\
{[0.76]}\end{array}$ & $\begin{array}{l}0.908 \\
{[1.22]}\end{array}$ & $\begin{array}{l}0.595 \\
{[0.42]}\end{array}$ \\
\hline Latin America & {$\left[\begin{array}{l}-0.667 \\
{[-0.55]}\end{array}\right.$} & $\begin{array}{l}4.317 \\
{[2.73]^{* * *}}\end{array}$ & $\begin{array}{l}-0.046 \\
{[-0.03]}\end{array}$ & $\begin{array}{l}5.436 \\
{[3.64]^{* * *}}\end{array}$ \\
\hline Small country & $\begin{array}{l}-2.503 \\
{[-1.90]^{*}}\end{array}$ & $\begin{array}{l}0.560 \\
{[0.67]}\end{array}$ & $\begin{array}{l}-1.894 \\
{[-1.89]^{*}}\end{array}$ & $\begin{array}{l}1.128 \\
{[1.29]}\end{array}$ \\
\hline Jus san. $\mathrm{X}$ average migration stock & {$\left[\begin{array}{l}0.140 \\
{[1.65]^{*}}\end{array}\right.$} & $\begin{array}{l}0.040 \\
{[0.61]}\end{array}$ & & \\
\hline Civil legal origin $\mathrm{X}$ migration stock & & & $\begin{array}{l}0.019 \\
{[0.23]}\end{array}$ & $\begin{array}{l}-0.110 \\
{[-1.10]}\end{array}$ \\
\hline Government consumption & $\begin{array}{l}0.036 \\
{[1.09]}\end{array}$ & $\begin{array}{l}0.063 \\
{[2.65] * * *}\end{array}$ & $\begin{array}{l}0.043 \\
{[1.25]}\end{array}$ & $\begin{array}{l}0.068 \\
{[2.59]^{* * *}}\end{array}$ \\
\hline Share of young & $\begin{array}{l}-0.197 \\
{[-1.78]^{*}}\end{array}$ & $\begin{array}{l}-0.402 \\
{[-2.46]^{* *}}\end{array}$ & $\begin{array}{l}-0.096 \\
{[-1.16]}\end{array}$ & $\begin{array}{l}-0.247 \\
{[-1.98]^{* *}}\end{array}$ \\
\hline Catholic share & $\begin{array}{l}0.012 \\
{[1.52]}\end{array}$ & $\begin{array}{l}0.011 \\
{[0.75]}\end{array}$ & $\begin{array}{l}0.006 \\
{[0.81]}\end{array}$ & $\begin{array}{l}0.017 \\
{[1.38]}\end{array}$ \\
\hline Ethnolinguistic fractionalization & $\begin{array}{l}-0.035 \\
{[-0.03]}\end{array}$ & $\begin{array}{l}1.290 \\
{[1.03]}\end{array}$ & $\begin{array}{l}1.029 \\
{[0.85]}\end{array}$ & $\begin{array}{l}1.950 \\
{[1.74]^{*}}\end{array}$ \\
\hline Political rights & $\begin{array}{l}0.539 \\
{[2.78]^{* * *}}\end{array}$ & $\begin{array}{l}0.436 \\
{[2.52]^{* *}}\end{array}$ & $\begin{array}{l}0.563 \\
{[2.58]^{* *}}\end{array}$ & $\begin{array}{l}0.276 \\
{[1.56]}\end{array}$ \\
\hline Constant & $\begin{array}{l}3.831 \\
{[1.08]}\end{array}$ & $\begin{array}{l}11.273 \\
{[2.11]^{* *}}\end{array}$ & $\begin{array}{l}-3.567 \\
{[-1.04]}\end{array}$ & $\begin{array}{l}4.527 \\
{[1.01]}\end{array}$ \\
\hline Observations & 224 & 224 & 224 & 224 \\
\hline Log likelihood & -95.74 & & -132.01 & \\
\hline Maximum Likelihood R2 & 0.68 & & 0.55 & \\
\hline McFadden's R2 & 0.57 & & 0.41 & \\
\hline McFadden's Adj R2 & 0.44 & & 0.28 & \\
\hline Cragg \& Uhler's R2 & 0.78 & & 0.64 & \\
\hline Count R2 & 0.83 & & 0.75 & \\
\hline Adj Count R2 & 0.64 & & 0.48 & \\
\hline
\end{tabular}

${ }^{\S}$ Jus sanguinis is the reference category. Robust $\mathrm{z}$ statistics in brackets, clustered at country level.

* significant at $10 \%$; * significant at $5 \%$; *** significant at $1 \%$ 
Table A.2

The Determinants of Citizenship Laws: Ordered Logit Estimates, 1950-2000

\begin{tabular}{|c|c|c|c|}
\hline & (a) & (b) & (c) \\
\hline & Citizenship laws & Citizenship laws & Citizenship laws \\
\hline Migration stock & $\begin{array}{l}-0.048 \\
{[-2.80]^{* * *}}\end{array}$ & $\begin{array}{l}-0.032 \\
{[-1.95]^{*}}\end{array}$ & $\begin{array}{l}-0.048 \\
{[-1.71]^{*}}\end{array}$ \\
\hline Jus sanguinis as initial citizenship law & $\begin{array}{l}-3.356 \\
{[-11.80] * * *}\end{array}$ & $\begin{array}{l}-3.452 \\
{[-9.25]^{* * *}}\end{array}$ & $\begin{array}{l}-4.113 \\
{[-6.40]^{* * *}}\end{array}$ \\
\hline Period & $\begin{array}{l}0.882 \\
{[3.22]^{* * *}}\end{array}$ & $\begin{array}{l}0.084 \\
{[0.24]}\end{array}$ & {$\left[\begin{array}{l}0.204 \\
{[0.37]}\end{array}\right.$} \\
\hline Decolonization & & $\begin{array}{l}-1.761 \\
{[-3.90]^{* * *}}\end{array}$ & $\begin{array}{l}-1.187 \\
{[-1.58]}\end{array}$ \\
\hline Southern Europe & & $\begin{array}{l}0.643 \\
{[1.31]}\end{array}$ & $\begin{array}{l}1.071 \\
{[1.80]^{*}}\end{array}$ \\
\hline Latin America & & $\begin{array}{l}2.616 \\
{[4.02]^{* * *}}\end{array}$ & $\begin{array}{l}3.756 \\
{[4.45]^{* * *}}\end{array}$ \\
\hline Small country & & $\begin{array}{l}0.27 \\
{[0.55]}\end{array}$ & $\begin{array}{l}0.502 \\
{[0.74]}\end{array}$ \\
\hline Jus san. $\mathrm{X}$ migration stock & & & $\begin{array}{l}0.045 \\
{[1.13]}\end{array}$ \\
\hline Government consumption & & & $\begin{array}{l}0.044 \\
{[2.59]^{* * *}}\end{array}$ \\
\hline Share of young & & & $\begin{array}{l}-0.24 \\
{[-2.32]^{* *}}\end{array}$ \\
\hline Catholic share & & & $\begin{array}{l}0.001 \\
{[0.17]}\end{array}$ \\
\hline Ethnolinguistic fractionalization & & & $\begin{array}{l}1.28 \\
{[1.52]}\end{array}$ \\
\hline Political rights & & & $\begin{array}{l}0.357 \\
{[2.93]^{* * * *}}\end{array}$ \\
\hline Observations & 300 & 300 & 224 \\
\hline Log likelihood & -210.85 & -174.82 & -117.59 \\
\hline Maximum Likelihood R2 & 0.4 & 0.52 & 0.61 \\
\hline McFadden's R2 & 0.26 & 0.39 & 0.47 \\
\hline McFadden's Adj R2 & 0.25 & 0.36 & 0.4 \\
\hline Cragg \& Uhler's R2 & 0.46 & 0.62 & 0.7 \\
\hline Count R2 & 0.71 & 0.78 & 0.79 \\
\hline Adj Count R2 & 0.32 & 0.5 & 0.56 \\
\hline
\end{tabular}

${ }^{\S}$ Jus sanguinis is the reference category. Robust $\mathrm{z}$ statistics in brackets, clustered at country level.

$*$ significant at $10 \% ; * *$ significant at $5 \% ; * * *$ significant at $1 \%$ 
Table A.3

Citizenship policy index and citizenship laws index: OLS Estimates, 1950-2000

\begin{tabular}{|c|c|c|}
\hline & $\begin{array}{l}\text { Citizenship } \\
\text { policy index }\end{array}$ & $\begin{array}{l}\text { Citizenship laws } \\
\text { index }\end{array}$ \\
\hline Migration stock in 1960 & $\begin{array}{l}0.003 \\
{[1.12]}\end{array}$ & $\begin{array}{l}-0.002 \\
{[-0.43]}\end{array}$ \\
\hline Jus sanguinis as citizenship law in 1948 & $\begin{array}{l}-0.078 \\
{[-1.24]}\end{array}$ & $\begin{array}{l}-0.223 \\
{[-2.10]^{* *}}\end{array}$ \\
\hline Decolonization & $\begin{array}{l}-0.153 \\
{[-2.08]^{* *}}\end{array}$ & $\begin{array}{l}-0.166 \\
{[-1.71]^{*}}\end{array}$ \\
\hline Southern Europe & $\begin{array}{l}-0.096 \\
{[-1.20]}\end{array}$ & $\begin{array}{l}0.110 \\
{[1.29]}\end{array}$ \\
\hline Latin America & $\begin{array}{l}0.387 \\
{[3.78]^{* * *}}\end{array}$ & $\begin{array}{l}0.555 \\
{[5.30]^{* * *}}\end{array}$ \\
\hline Small country & $\begin{array}{l}0.020 \\
{[0.27]}\end{array}$ & $\begin{array}{l}0.049 \\
{[0.40]}\end{array}$ \\
\hline Jus san. in 1948 X migration stock in 1960 & $\begin{array}{l}-0.007 \\
{[-2.14]^{* *}}\end{array}$ & $\begin{array}{l}0.002 \\
{[0.30]}\end{array}$ \\
\hline Government consumption & $\begin{array}{l}0.005 \\
{[1.62]}\end{array}$ & $\begin{array}{l}0.007 \\
{[1.95]^{*}}\end{array}$ \\
\hline Share of young & $\begin{array}{l}-0.025 \\
{[-2.18]^{* *}}\end{array}$ & $\begin{array}{l}-0.035 \\
{[-2.12]^{* *}}\end{array}$ \\
\hline Catholic share & $\begin{array}{l}0.000 \\
{[0.23]}\end{array}$ & $\begin{array}{l}0.000 \\
{[0.37]}\end{array}$ \\
\hline Ethnolinguistic fractionalization & $\begin{array}{l}0.147 \\
{[1.48]}\end{array}$ & $\begin{array}{l}0.190 \\
{[1.62]}\end{array}$ \\
\hline Political rights & $\begin{array}{l}0.026 \\
{[1.57]}\end{array}$ & $\begin{array}{l}0.038 \\
{[1.45]}\end{array}$ \\
\hline Constant & $\begin{array}{l}1.098 \\
{[2.57]^{* *}}\end{array}$ & $\begin{array}{l}1.259 \\
{[1.95]^{*}}\end{array}$ \\
\hline Number of observations & 104 & 119 \\
\hline R-squared & 0.549 & 0.536 \\
\hline Adjusted R-squared & 0.489 & 0.483 \\
\hline
\end{tabular}

$\S$ The sample is a cross section with averages over the $1950-2000$ period. Robust standard errors in parentheses, clustered at country level.

$*$ significant at $10 \% ; * *$ significant at $5 \% ; * *$ significant at $1 \%$ 
Table A.4

The Determinants of Change in Citizenship Laws: Logit Estimates, 1950-2000 $\$$, Fixed and Random Effects

\begin{tabular}{|c|c|c|}
\hline & \begin{tabular}{|l|} 
Fixed effects \\
\end{tabular} & Random effects \\
\hline & Change in cit. laws & Change in cit. laws \\
\hline Migration stock & $\begin{array}{l}0.115 \\
{[0.74]}\end{array}$ & \begin{tabular}{|l|}
0.031 \\
{$[0.84]$}
\end{tabular} \\
\hline Jus sanguinis as initial citizenship law & $\begin{array}{l}-0.979 \\
{[-0.94]}\end{array}$ & $\begin{array}{l}-1.133 \\
{[-2.03]^{* *}}\end{array}$ \\
\hline Period & $\begin{array}{l}1.256 \\
{[1.64]}\end{array}$ & $\begin{array}{l}1.466 \\
{[2.32]^{* *}}\end{array}$ \\
\hline Decolonization & $\begin{array}{l}3.019 \\
{[2.15]^{* *}}\end{array}$ & $\begin{array}{l}2.677 \\
{[3.91]^{* * *}}\end{array}$ \\
\hline Southern Europe & & $\begin{array}{l}1.943 \\
{[2.09]^{* *}}\end{array}$ \\
\hline Latin America & & $\begin{array}{l}-2.356 \\
{[-2.04]^{* *}}\end{array}$ \\
\hline Small country & & {$\left[\begin{array}{l}-0.636 \\
{[-0.97]}\end{array}\right.$} \\
\hline Jus san. $X$ migration stock & $\begin{array}{l}0.009 \\
{[0.08]}\end{array}$ & {$\left[\begin{array}{l}-0.017 \\
{[-0.29]}\end{array}\right.$} \\
\hline Government consumption & $\begin{array}{l}0.057 \\
{[0.81]}\end{array}$ & {$\left[\begin{array}{l}-0.023 \\
{[-1.10]}\end{array}\right.$} \\
\hline Share of young & $\begin{array}{l}-0.067 \\
{[-0.24]}\end{array}$ & $\begin{array}{l}-0.199 \\
{[-2.00]^{* *}}\end{array}$ \\
\hline Catholic share & & $\begin{array}{l}0.000 \\
{[0.06]}\end{array}$ \\
\hline Ethnolinguistic fractionalization & & $\begin{array}{l}1.227 \\
{[1.44]}\end{array}$ \\
\hline Political rights & $\begin{array}{l}-0.009 \\
{[-0.02]}\end{array}$ & $\begin{array}{l}0.112 \\
{[0.87]}\end{array}$ \\
\hline Constant & & $\begin{array}{l}3.844 \\
{[1.13]}\end{array}$ \\
\hline Observations & 92 & 224 \\
\hline Number of groups & 46 & 118 \\
\hline Log likelihood & -16.282 & -85.046 \\
\hline
\end{tabular}

* significant at $10 \%$; * significant at $5 \% ; * * *$ significant at $1 \%$ 